Seyahat ve Otel İşletmeciliği Dergisi/

Journal of Travel and Hospitality Management

17 (2), 2020, 203-231.

Gönderim Tarihi: 30.12 .2019

Kabul Tarihi:24.03.2020

DOI:10.24010/soid.665678

Araştırma Makalesi/Research Article

\title{
Bölgesel Kalkınmada Turizm Girişimciliğinin Rolü: Akçakoca Örneği ${ }^{\star}$
}

\section{The Role of Tourism Entrepreneurship in Regional Development: Case of Akçakoca}

Dr. Öğr. Üyesi Zeynep MESci

Düzce Üniversitesi

Akçakoca Turizm İşletmeciliği ve Otelcilik

Yüksekokulu, Düzce, Türkiye

E-posta: zeynepmesci@duzce.edu.tr
Arzu KARAGÖZ

Düzce Üniversitesi

Sosyal Bilimler Enstitüsü,

Düzce, Türkiye

E-posta: arzukaragoz93@hotmail.com

Öz

$\mathrm{Bu}$ araştırmanın amacı, Cittaslow (Sakin Şehir) olma yoluna giren Akçakoca ilçesinin kırsal turizm kapsamında değerlendirilebilecek alanlarında faaliyet gösteren turizm girişimcilerinin bölgesel kalkınmadaki rollerinin belirlenmesi ve bölgesel kalkınmaya katkı sağlayıp sağlamadıklarının değerlendirilmesidir. Çalışmanın alt amaçları; turizm girişimcilerinin temel sorunlarının ele alınması, turizm girişimciliğini tehdit eden unsurların belirlenmesi ve Akçakoca ilçesindeki turizm girişimcilerinin geliştirilmesine ve sayılarının arttırımasına yönelik öneriler sunulmasıdır. Çalışmada veriler, yarı yapılandırılmış mülakat tekniğiyle 18 turizm girişimcisi ile görüşülerek elde edilmiştir. Araştırma sonucunda, turizm girişimcilerinin hem bölgesel kalkınmada hem de bölgede turizmin gelişmesinde etkin rol oynadığı belirlenmiştir. Turizm girişimcileri kurmuş oldukları işletmeler sayesinde bölgede gelir artı̧ına, yeni istihdam olanaklarının oluşumuna ve ziyaretçi memnuniyet düzeyinin artış göstermesine katkı sağlamaktadırlar. Ortaya çıkarılan bu olumlu sonuçlara karşıt olarak yerel yönetimlerin turizm girişimciliğinin teşvik edilmesi ve geliştirilmesi kapsamında yeterli olmadığı sonucuna ulaşılmıştır. Bu bağlamda, turizm potansiyeli olan bölgelerde turizm sektörüne yapılan yatııımların bölge için önem arz etmesi bakımından turizm sektöründe faaliyette bulunan girişimcilerin tespit edilmesi ve bölgesel kalkınmaya katkısının belirlenmesi bu çalışmayı önemli kılmaktadır.

Anahtar Kelimeler: Bölgesel Kalkınma, Turizm, Girişimcilik, Turizm Girişimciliği, Akçakoca.

\section{Abstract}

The aim of this research is to determine the roles of tourism entrepreneurs operating in areas that can be evaluated within the context of rural tourism in the district of Akçakoca, which is on the way of becoming Cittaslow, and to assess whether it contributes to regional development. Sub objectives of the study; addressing the main problems of tourism entrepreneurs, identifying the elements threatening tourism entrepreneurship and to offer suggestions for the development of tourism entrepreneurs in Akçakoca district and increasing their number. The data in the study was obtained by interviewing 18 tourism entrepreneurs using a semi-structured interview technique. As a result of the research, it has been determined that tourism entrepreneurs play an active role both in regional development and in the development of tourism in the region. Thanks to the businesses they have established, tourism entrepreneurs contribute to the increase in income in the region, the creation of new employment opportunities and an increase in visitor satisfaction. Contrary to these positive results, it has been concluded that local governments are not sufficient within the scope of promoting and developing tourism entrepreneurship. In this context, in terms of the importance of investments made in the tourism sector in regions with tourism potential for the region; Identifying the entrepreneurs operating in the tourism sector and determining their contribution to regional development makes this study important.

Key Words: Regional Development, Tourism, Entrepreneurship, Tourism Entrepreneurship, Akçakoca.

${ }^{*} B u$ çalışma, Dr. Öğr. Üyesi Zeynep MESCl'nin danışmanlığında Düzce Üniversitesi Sosyal Bilimler Enstitüsü Turizm ve Otel İşletmeciliği Anabilim Dalı'nda hazırlanan Arzu KARAGÖZ'ün "Bölgesel Kalkınmada Turizm Girişimciliğinin Rolü: Akçakoca Örneği " adlı yüksek lisans tezinden üretilmiştir. 


\section{Giriş}

Turizm endüstrisi, kar amacı olmayan turizm organizasyonları, pazarlama hizmetleri, konaklama, ulaşım, yeme-içme, perakende satış mağazaları gibi farklı türden hizmetleri ve faaliyetleri bir araya toplayan koruyucu, uyarıcı ve sürükleyici bir yapıya sahiptir. Bu özelliği, gerçekleştirdiği ve başardığı çok yönlü olan işlevlerinden ve ekonomiye sağladığı katkılarından dolayı olmaktadır (Halis ve Ulama, 2015: 39). Turizm; bölgesel kalkınmanın teşvik edilmesi, ulusal ekonominin çeşitlendirilmesi, kamu gelirlerinin arttırılması, istihdam alanları oluşturulması, gelir seviyelerinin iyileştirilmesi ve ödemeler dengesi gibi pek çok ekonomik sürece katkı sağlamaktadır (Lerner ve Haber, 2001: 78). Bunun yanında uluslararası pazarlarda hızlı bir biçimde gelişme göstermesi, turizmi girişimcilik olgusuyla katılımı gerektiren sektörlerden birisi haline getirmiştir. Yeni fikirler geliştirilip yeni pazarlar oluşturulmasında, tüketicilerin turizm sektöründe hızla farklılaşan taleplerinin karşılanmasında ve kalkınmanın kolaylaştııımasının sağlanmasında, yeni işletmeler kurulmasının anahtarı olan girişimciliğin önemli bir rol oynadığına inanılmaktadır (Lordkipanidze vd., 2005: 787; Sheikh, 2015:7). Bu bakımdan ülkelerin, bölgelerin veya yörelerin kalkınmasında; girişimcilerin özellikleri, yatırımları, kurdukları işletmelerin büyüklüğü ve çeşitliliği, teknolojik özellikleri ve rekabet dereceleri önem arz eden unsurlar olarak görülmektedir. Bu alanlara katkı sağlama turizm sektörüne yapılan yatırımlar yoluyla meydana gelmektedir (Aydemir vd.,2011: 552). Bu da girişimcilik yetenekleri yüksek olan toplumlarda daha yüksek seviyede olmakta bu sayede de turizm sektörü gelişim göstermektedir. Bunun sonucunda da turistik mal ve hizmetlerin üretimini sağlayan ve turistlerin intiyacını gideren irili ufaklı birçok iş alanı ortaya çıkmaktadır (Tokmak ve İnce, 2014: 110). Bu bağlamda, turizm ürünlerini üreten ve yöneten bir kişi veya gruplar Khanka'ya (1999) göre, turizm girişimcisi olarak tanımlanmakta ve özellikle kırsal bölgelerde iş geliştirmenin sürdürülmesi için stratejik destek sağlamanın temel yolunun turizm girişimciliğinden geçtiği kabul edilmektedir (Nongsiej ve Shimray, 2017: 3). Turizm girişimciliği, yasal bir turizm işletmesinin kurulması, işletilmesi ve turistlerin intiyaçlarını karşılamaya çalışan işletmeler ile ilgili faaliyetleri kapsamaktadır (Bagherifard vd., 2013: 843).

Turizm potansiyeli bakımından zengin olan bölgelerde, turizm sektörüne yapılan yatırımlar önem arz etmekte ve bu bakımdan turizm sektöründe faaliyette bulunan girişimcilerin tespit edilmesi ve bölgesel kalkınmaya katkısının belirlenmesi önem arz eden başka bir konudur. Bu çalışmanın amacı, Türkiye'de ilk turizm hareketlerinin başladığı yerlerden biri olan Akçakoca'nın, kırsal turizm kapsamında değerlendirilebilecek alanlarında faaliyet gösteren turizm girişimcilerinin tespit edilerek; bölgesel kalkınmadaki rollerinin belirlenmesi ve bölgesel kalkınmaya katkı sağlayıp sağlayamadıklarının ortaya koyulmasıdır. Ayrıca turizm girişimcilerinin temel sorunlarının tespit edilmesi, turizm girişimciliğini tehdit eden unsurların belirlenmesi ve Akçakoca ilçesindeki turizm girişimcilerinin geliştirilmesine ve sayılarının artırılmasına yönelik öneriler sunulması alt amaçlar olarak belirlenmiştir. Akçakoca'nın seçilme sebebi pek çok turistik unsura sahip olması, kırsal turizm alanlarının gelişmeye açık olması, destinasyonun Cittaslow (Sakin Şehir) hareketine aday gösterilmesi ve bu amaçla çalışmalara başlanmış olmasıdır.

\section{Bölgesel Kalkınmada Girişimcilik ve Önemi}

Bölgesel kalkınma kısaca bir bölgenin veya yörenin refah seviyesindeki artış olarak tanımlanabilir (Çeken, 2008: 296). Ayrıca, ekonomik kalkınmanın bir ürünü olarak; refah seviyesinin, yatırım hacminin, yaşam standartlarının ve çalışma şartlarının daha iyi hale getirilmesini ifade ederken, ekonomik bir süreç olarak; endüstrinin 
desteklenmesi, altyapının iyileştirilmesi, işgücü ve piyasalarının geliştirilmesini ifade etmektedir. Bölgesel kalkınma ve yatırımın desteklenmesinde rekabetçi bir ortam oluşturmak için gerekli olan koşullar; yetkin bir işgücü, etkili kurumlar, iyi gelişmiş altyapı, finans ve lojistik sistemlerdir. Bu gibi unsurlar, bölgesel yönetimlerin ve kurumların kalkınma ve yatırımları desteklenmesinde inşa etmesi gereken stratejik altyapı olarak adlandırılabilir. Bunun yanında, yenilik ve yeni ürün-hizmetlerin ticarileştirilmesine odaklanan iyi geliştirilmiş iş ağlarına intiyaç duyulmaktadır. Bunlar da özel sektörde gerçekleşen faaliyetler olmaktadır (Stimson vd., 2006: 4-9).

Girişimcilik kavramı ise sanayi toplumundan bilgi toplumuna geçilmesinin ardından önem kazanmış en fazla ilgi çeken konulardandır (Paksoy ve Aydoğdu, 2010: 119). Bilimsel olarak ele alınış önceliği Fransız bilim adamları tarafından olup, sözcük olarak Fransızca "entreprendre" sözcüğünden gelmiştir. İlk kez Fransız düşünür ve yazarlarından J.B.Say tarafından kullanılarak literatüre onun aracılığıyla girmiştir. Cantillon da aynı şekilde Say'ı takip ederek girişimcilik kelimesini sıklıkla kullanmıştır. Cantillon ve Say'a göre, bir ekonomiyi yönlendiren, tüketici ve tedarikçi ortasında bulunarak işin merkezinde olan ve üretimi organize eden etkin kişiler girişimcilerdir (Top, 2012:4-5). İşletme yönetimi literatürüne göre girişimcilik, karını maksimize etmek isteyen bireyler tarafından gerçekleştirilen, süreci ise başarıya bağlı faaliyetler olarak ele alınmaktadır. "Iş yaratma" eylemi girişimciler tarafından gerçekleştirilirken, "ihtiyaçların karşılanması" iş adamları tarafından gerçekleştirilmektedir. Bu da girişimciyi iş adamlarından ayıran farklılıktır (Safian, 2012: 23). Girişimciliği inovasyon yapan kişi olarak tanımlamış Schumpeter (1986)'e göre girişimci yeniliği beş şekilde ortaya çıkmaktadır. Bunlar; yeni bir ürünün sunulması veya bir ürünün kalitesinde yenilik uygulanması, üretimde yeni yöntemler geliştirilmesi, yeni pazarların keşfedilmesi, hammaddeye ulaşılmasında yeni kaynakların bulunması ve yeni bir organizasyon yapısının her endüstride gerçekleştirilmesi şeklindedir (Halis ve Ulama, 2015: 24). Girişimciler yeni işler, yeni ürünler ve servis oluşturarak rekabeti arttırır ve ayrıca teknolojik değişimler yoluyla da verimliliği arttırarak bireylerin yaşamlarına katkı sağlarlar. Bu açıdan da bir ülkede ekonomik büyüme ve kalkınma girişimcilik faaliyetleriyle ilişkili olmaktadır (Önce vd., 2014: 63). Girişimcilerin işletme başarılarının yanında yöresel, bölgesel ve ulusal kalkınmada da aktif bir özellik gösterdiği görülmekte ve bu sebeple de; yerel, bölgesel ve ulusal kalkınmanın önemli bir unsuru haline gelmiş oldukları görülmektedir (Özkul ve Dulupçu, 2007: 74). Bölgesel/yerel girişimciliğin geliştirilmesi ve kolaylaştırılması, sürdürülebilir kalkınmayı yerel kalkınmaya entegre etmeye çalışan turizm politikası oluşturucuları için önemli bir sorun haline gelmiştir. Küçük işletmeler kalkınma alanlarında girişimciliğin temel araçları olmakla birlikte, literatürde de küçük işletme ve girişimcilik hakkındaki araştırmalar sıklıkla iç içedir (Nikolovski vd., 2017: 119).

Girişimciliğin teşvik edilmesi bölgesel kalkınma stratejisi olarak sunularak, yatırım yapmanın cazip hale getirilmesi yoluyla bölgelere canlandırma etkisi sağlanmaktadır. Gelişmişlik farkları sorunu, gelişmiş ve gelişmekte olan ülkelerin temel sorunlarından biridir. Bu sebeple geri kalmış bölgelerin canlandırılmasının sağlanması girişimcilik olgusundan geçmektedir. Az gelişmiş bölgeler için ise sermayenin bu bölgelere kaymasını sağlayarak bu bölgelerin cazip hale getirilmesi, yatırımların gelişmesinin ve büyümesinin elverişli hale gelmesini sağlayacaktır. Bu bağlamda, devlet ve uluslararası kuruluşların yapılması gerekli olan alt yapı yatırımlarının gerçekleştirilmesine yönelik teşvik ederek destek vermesi, bölgelerde girişimcilik olgusunun çoğalmasında önemli bir faktördür (Özkul ve Dulupçu, 2007: 75). Girişimcilik kültürünü eğitim sistemi ve medya kapsamı yoluyla teşvik etmek, bu sorunu ele almanın yollarından biridir. Buna ek olarak; mali teşvikler, genel sübvansiyonlar, işgücü piyasası düzenlemeleri ve iflas kanunları, girişimcinin bir işletme sahibi olarak hareket 
etme veya ücretli istihdamı kabul etme gibi net ödülleri ve riskleri karşılaştırmasına yardımcı olur (Nikolovski vd., 2017: 116). Yeni firmaların doğumunu sağlayan girişimcilik çalışmalarının yerel ekonomik kalkınmayı etkileyebileceği yollar Tablo 1'de özetlenmiştir (Organisation for Economic Co-operation and Development, 2003: 43-45; Özkul, 2008: 48-49):

\section{Tablo 1: Girişimciliğin Yerel Ekonomik Kalkınmaya Etkileri}

İstihdam ve Gelir Artışı

Vergi Gelirlerinde
Artış

Yeni firmaların kurulmasında ve büyütülmesinde yapılan yatırımlar, işletme sahipleri ve çalışanları için iş sağlamaktadır. $\mathrm{Bu}$ da toplum için gelirin çarpan etkisini arttıracaktır. Küçük firmalar genelde kendi bölgesinde kalma eğiliminde olup daha geniş pazarlara satış yaparak gelir getirmekte ve farklı bölgelere ait gelirleri oldukları bölgelere taşınmasını sağlamaktadır.

Bölgenin vergi tabanındaki büyüme; kişisel gelirler, şirket karları, tüketim, mülk değerleri ve bordro ödemelerindeki artıştan kaynaklanmaktadır.

Yeni firmaların oluşturulması, perakende satış tesisleri gibi yerel

Geliştirilmiş

Hizmet Sunumu

Sağlama ve

Bölgesel Geliri

Elde Tutma

Canlandırma ve Motivasyon Etkisi

\section{Cazibe Merkezi OIma}

Toplumsal Hayata Etki hizmetlerin sunumunu geliştirmektedir. Yerel hizmet tedarikindeki bir artış, bölgedeki gelirlerin korunmasına ve bölgede tutulmasına yardımcı olabilmektedir. Oluşturulan işletmeler ile bu hizmetlere olan talep artış göstermektedir. Ayrıca hizmetlerin sağlanmasından doğan genişleme ile de bir konumu diğerlerinin de bir işletme kurması veya bulması için daha cazip bir yer haline getirebilmektedir.

Yeni şirketlerin doğması ve yayılımı sonucunda yoksul alanlarda canlandırıcı etkiler oluşabilmekte ve bu da insanların motivasyonunu olumlu olarak etkileyebilmektedir.

Bir bölgede girişimcilik faaliyetlerinin çokluğu, o bölgenin alt yapısının yeni yatırımlar için uygun olduğunu göstermektedir. Bunun sonucunda diğer bölgelerdeki sermaye bu bölgeye doğru kayma gösterecektir. Bu yönüyle girişimcilik olgusu, yatırımların bölgeye çekilmesinde dikkat çeken önemli bir konudur.

Girişimciliğin ve işletme sayılarının artış göstermesi, ekonomik yönünün olması yanında sosyal ve toplumsal yönüyle de bölgenin gelişmesinde katkısı olmaktadır. Bu bölgelerde geçinen insanların alım gücünün yükselmesi sonucunda refaha ulaşmaları ve mutlu olarak yaşamlarına devam etmeleri sağlanacaktır.

Kaynak: OECD, 2003: 43-45; Özkul, 2008: 48-49; Perktaş, 2014:482'den uyarlanmıştır.

Ekonomik kaynaklar girişimciler tarafından verimli alanlara yöneltilerek ve üretim kaynakları ortaya koyulan yeni tarzlarla kombine edilerek sonucunda üretim faktörleri ortaya çıkarılmaktadır. Bu sebeple girişimci bireyler bulundukları ve yaşamını sürdükleri topluma karşı önemli bir görev üstlenmiş olurlar. Bu misyonlar toplumsal ve ekonomik açıdan birçok işlevi yerine getirmektedir (Marangoz, 2017: 82). Hem firma düzeyinde hem de ürün üretim ve pazarlama faaliyetlerindeki yeniliklerle hızlı şekilde gelişim gösteren girişimciler bunun yanı sıra, ilişkili sektör ortamında örgütlenerek, ulusal ve uluslararası düzeyde beklenti ve çıkarlarını ortak bir ifade olarak belirtmektedir. Ayrıca yeniliğe bağlı olan girişimciler, yeniliğe en duyarlılık gösteren imalat ve hizmet sektöründe yoğunlaşmıştır. Girişimci faaliyetlerden etkilenen bu sektörlerin kutuplaştıkları ve milli gelirde artış gösterdikleri söylenebilmektedir (Kasalak, 2014: 262). 


\section{Turizm Girişimciliği}

Değişim, kalkınma, yenilikçilik ve yönetim konularının girişimcilik bakımından gittikçe daha fazla yer aldığı alanlar konaklama, eğlence, spor ve turizm endüstrileri olmuştur. $\mathrm{Bu}$ endüstrilerde girişimcilik olgusu tüketicilerin değişen taleplerine yanıt vermede önemli rol oynamakta ve ayrıca değişim, yenilik ve istihdamın itici bir gücü olmaktadır. Bu aşamada girişimciler yeni ürünler ve hizmetler, yeni üretim metotları, yeni piyasalar, yeni kaynaklar ve yeni endüstri organizasyonları geliştirmektedirler (Ball, 2005: 5-6; Kapu vd., 2012: 52). Ekonomik kalkınmanın merkezi bir gücü olarak kabul edilen girişimcilik, turizm sektörüne katılımı gereken ekonomik sektörlerden biri olmuştur. Artan yeni turizm intiyaçlarından doğan taleplerle başa çıkmak için turizm ürün ve hizmetlerinin çeşitlendirilmesi gerekmekte bu da daha sürdürülebilir turizm olgusu için fırsatlar içermektedir (Lordkipanidze vd., 2005: 787). Turizm sektörü sürekli değişim halindedir. Bu değişim hem piyasa trendlerini hem de tüketici talebinin karşılanma yöntemlerine etki eden birçok sayısız sosyoekonomik ve teknolojik faktör tarafından yönlendirilmiştir. Meydana gelen fırsatları sürekli olarak tanımlayan ve bunları takip edecek örgütleri oluşturan kişiler girişimciler olmuştur. Yani kısaca değişimin ana aktörlerinden biri görevindedir (Russell ve Faulkner, 2004: 556-557). Turizm girişimciliği; toplumsal sorunların çözülmesinde ve bir ülkenin GSYIH (Gayri Safi Yurt İçi Hâsıla)'sindeki artışı sağlayarak büyüme ve gelişme konularına katkı sağlamaktadır. Böylece turizm sektörü ekonomik ve sosyal değişimlerdeki değişim aracı olmanın yanında, istihdam konusunda da fırsatlar için vazgeçilmez bir role sahiptir (Nongsiej ve Shimray, 2017: 1). Koh (1996: 24)'a göre turistik işletmeler bir toplumun ekonomik ve sosyal refahına önemli derecede katkı sağlayabilmektedir. Bu bakımdan da, bir toplumun turistik işletmelerinin varlığının arttırımasında en pratik yöntem olarak yerli turizm girişimcilerinin arzının arttırılması görülmektedir. Turistik girişim oluşturma sürecinin belirlenmesi ve turizm girişimciliğinin teşvik edilmesi için uygun politikalar geliştirilmesi buna ulaşmak için elverişli yollardan biri olmaktadır.

19. yüzyılda destinasyon ve bölgelerin tanıtımları ile ilgili çalışan reklam komiteleri ya da demiryolu ve vapur şirketleri turizm girişimciliğinin ilk örneği olarak verilebilmektedir. Bu tür girişimlerin sonucunda çekici seyahat rehberlerinin ve posterlerin artması sağlanmıştır. Thomas Cook, başarı sağlamak için çok sıkı bir program ve önceden belirlenmiş maliyet ile denetimli turların teminini gerçekleştirmiş ve turizm pazarının gelişim göstermesine önderlik eden ilk girişimci örneği olmuştur. Turizm amaçlı kitleler için Coney Adası, elitler için Florida ve Newport, Gettysburg gibi örnek alanlar önemli destinasyonlar olarak öne çıkmıştır (Kozak vd., 2015: 61). Thomas Cook'un tur paketleri, Ray Kroc'un McDonalds'ı, Walt Disney'deki tema parkları, J.W. Marriot'un ve Conrad Hilton'un otelleri, konaklama ve seyahat işletmeleri dünyasında klasik girişimcilik markası olarak ortaya çıkan örneklerdendir. Bu başarılı girişimciler fırsatlara odaklanarak muhalefet ve gerileme karşısında özveri ve cesaret sergileyerek konaklama ve seyahat endüstrisi tarihine isimlerini ve işletmelerini yazmışlardır (Ateljevic ve Li, 2009: 10). Günümüzdeki yeni turizm girişimcilik süreçleri, turizm ve konaklama pazarında birçok yeni turizm türü ve yenilikçi uygulamaların üretilmesi ile piyasaya sürülmesine yol açmıştır. Bunun sonucu olarak pazara sunulan bazı popüler örnekler ise; yerel gastronomi turizmi, kırsal macera turizmi (yerel cazibe merkezlerine özel), sürdürülebilir bölgesel eko turizm paketleri, yumuşak turizm, özel yerel etkinlikler ve festivaller, yerel karanlık turizm, tarım-turizm çiftlikleri, otantik ve etnik aile temelli restoranlar olmuştur (Pırnar, 2015: 82).

Turizm girişimciliği, turizm sektörü için turist intiyaçlarının giderilmesinde; ürün ve hizmetlerin üretimi, geliştirilmesi ve ticarileştirilmesinde aktif olan kamu ve özel kuruluşların faaliyetlerinin birleştirilmiş halidir. Küçük bireysel girişimlere ait kentsel ya 
da kırsal alanlarda mikro ekonomik ve makroekonomik seviyede faaliyette bulunarak geniş bir turizm hizmeti çeşitliliği sağlamaktadır. Bu hizmetler; ulaşım, otel, yemek servisi, misafir evleri, seyahat acenteleri, eğlence, sağlık ve fitness kulüpleri, sanat ve el işi eserlerinin üretimi ve ticareti, spor turizmi ve bahçelerden yerel müzelere kadar sayılabilen turistik mekânlar olarak çeşitlendirilebilmektedir (Rusu vd., 2012: 25). Kırsal turizm veya eko turizm açısından turizm girişimciliğine ait hizmetler ise; hobi bahçeleri, at biniciliği, paintball, macera parkı, kırsal pansiyon ve sportif olta balıkçılığına ait tesisler, ekolojik otel, çiftçilik girişimciliği, rafting (lastik bot ve kano işletmeciliği), yöresel lokanta ve sertifikalı, kontrollü avlak sahası işletmeciliği olarak sıralanabilmektedir (Zurnacı, 2012: 67). Bu türler içinde günümüzde en çok kırsal pansiyon, ekolojik otel ve çiftçilik girişimciliği ilgi uyandırmaktadır (Tekin ve Kasalak, 2014: 131).

Turizm girişimciliğinin akademik bir çalışma alanı olarak, 1970 ve 1980'lerde daha çok işletme ekonomisi ve ekonomik coğrafya alanında yayınlanmış birkaç makaleden sonra daha çeşitli araştırma alanlarıyla ortaya çıktığı gözlemlenmiştir (Solvoll vd., 2015: 121). Koh'a (1996: 30) göre, turistik teşebbüs yaratan veya yaratmaya teşebbüs eden kişi turizm girişimcisidir. Ayrıca bir turizm işletmesinin başlatılarak işletilmesi ile ilgili tüm risk ve belirsizlikleri üstlenen bireylerdir. Tek bir şahıs ya da birden fazla kişinin toplanmasıyla da işletmeler kurulabilmektedir (Koh ve Hatten, 2002: 25). Başka bir ifade ile; ev sahipleri, oda ve kahvaltı tesisleri, restoran, kahve dükkânları ve küçük kafeler, hediyelik eşya dükkânları, seyahat acenteleri, ulaşım, parklar, rekreasyon ve tur operatörleri olarak küçük ve orta ölçekli işletmeler halinde mal ve hizmet oluşturma fırsatlarının ortaya çıkarılması için işletmeler ortaya çıkan bireylerdir (Matsiliza, 2017: 2). Kısaca turizm girişimcileri bulundukları alanlardaki kaynakları turistik mekânlara dönüştürme yetisinin yanında dinamik, yaratıcı, uzun vadede turizmin gelişimini destekleyen ve turizm kültürünün oluşturulmasını etkileme bakımından anahtar role sahiptirler (Mottiar, 2015: 2). Koh ve Hatten'e (2002: 32) göre turizm girişimcilerini, genel girişimcilerden ayıran 6 farklılık bulunmaktadır.

\section{Şekil 1: Turizm Girişimcilerinin Genel Girişimcilere Göre Farklılıkları}

\begin{tabular}{|c|c|}
\hline & Turistik işletme kurması. \\
\hline \multirow{5}{*}{$\begin{array}{l}\text { Turizm } \\
\text { Girişimcisi }\end{array}$} & $\begin{array}{l}\text { Turizm ürününün, ortaya konulmadan denenememesinin } \\
\text { oluşturduğu risk ve kıyaslama yapııldığında daha fazla risk } \\
\text { oluşturması ve yatırımcı çekilmesinin zorluğu. }\end{array}$ \\
\hline & $\begin{array}{l}\text { Hizmet odaklı yönetim-pazarlama } \\
\text { bulundurma mecburiyetinin olması. }\end{array}$ \\
\hline & $\begin{array}{l}\text { Turizm girişimcileri mevsimsellikten daha çok etkilenmekte } \\
\text { olup, bunu daha dikkatli ve etkin bir şekilde ele almalarının } \\
\text { gerekliliği. }\end{array}$ \\
\hline & $\begin{array}{l}\text { Üretim ve tüketim yeri aynı olan turistik sunumlardan dolayı } \\
\text { turizm girişimcisinin daha çok belirsizlikle karşılaşması ve } \\
\text { kendi operasyonel ortamları üzerinde kontrolünün daha az } \\
\text { olması. }\end{array}$ \\
\hline & $\begin{array}{l}\text { Milli parklar ve tarihi yerler gibi birçok destinasyonun devlet } \\
\text { kurumlarına ait olması ve işletilmesi, bu yüzde turizm } \\
\text { girişimcisinin serbest piyasa sisteminde faaliyetlerinin } \\
\text { kısıtlanması. }\end{array}$ \\
\hline
\end{tabular}

Kaynak: Koh ve Hatten, 2002:32'den uyarlanmıştır. 
Turizmle ilgili bir işletmede girişimciliğin diğer iş türlerini işletmekten farkı, turizmin deneyimsel olduğu ve turistin turizm ürününün hem üretim hem de tüketiminde bulunmasıdır. Bu bakımdan turizm işletmesi, bireysel girişimciden daha fazla etki oluşturabilir, bunun sebebi ise bir turistin varış noktasını nasıl deneyimlediğine olan etkisidir (Deale, 2016: 3). Ayrıca bölgelerde küçük ve orta ölçekli turizm işletmelerinin yerel ekonomilerin gelişmesinde oluşturduğu katkı önem arz etmekte ve bu bakımdan da turizm girişimcilerinin özelliklerinin belirlenmesi bu katkının anlaşımasını sağlamaktadır. Bir bölgede turizmin gelişmesi turizm girişimcilerinin özelliklerine, çevresel koşullara ve destinasyon yaşam basamağına bağlanmıştır (Kale, 2016: 160). Koh ve Hatten (2002: 33-39)'e göre turizm sektöründe tek bir girişimci türü olmamakta, davranışsal yaklaşıma ve ürün farklılaşmasına göre kategorize edilmektedir. Davranışsal yaklaşıma göre 6 tür turizm girişimcisi görülmekteyken, ürün çeşitlenmesi sınıflandırmasına göre 3 tür turizm girişimcisi görülmektedir. Davranışsal yaklaşıma göre turizm girişimcileri Tablo 2'de gösterildiği gibi belirtilmektedir:

Tablo 2: Davranışsal Yaklaşıma Göre Turizm Girişimcileri

\section{Sosyal turizm girişimcisi \\ (the social tourism enterpreneur) \\ Yaşam tarzı turizm girişimcisi \\ (the lifestyle tourism enterpreneur)}

\section{Marjinal turizm girișimcisi}

(the marginal tourism enterpreneur)

Gizli turizm girişimcisi (the closet tourism enterpereneur)

Doğmakta olan turizm girişimcisi

(the nascent tourism enterpreneur)

\section{Seri turizm \\ işletmecisi (the serial tourism enterpreneur)}

Farklı sebeplerden dolayı kar amacı gütmeyen turizm işletmesi kuran girişimcilerdir (müzeler, akvaryumlar, sanat galerileri, bahçe vb.).

İşletmelerini büyütme niyeti olmadan istedikleri yaşam tarzlarına ve hobilerine uygun alanları desteklemek için turistik girişimlerde bulunan bireylerdir (yemek pişirmekten hoşlanan bireylerin yeni kişilerle tanışma fırsatı sağlama maksadıyla işletme açması vb.).

Enformel sektör içinde işletme çalıştıran girişimcileridir. Lisanssız tur rehberleri ve sokak satıcıları örnek verilebilir. Çalışan olmayıp bağımsız iş sahipleridir. Bununla birlikte, kayıt dışı sektör işletmeleri yasal/onaylanmış faaliyetler olmadığından dolayı gerçek turizm girişimcileri olarak nitelendirilemezler.

Değişik sebeplerden dolayı tam zamanlı işlerinin yanında turistik işletme çalıştırırlar. Örnek olarak bir üniversite profesörünün mevsimlik olarak tur şirketi işletmesi verilebilir.

Turistik işletme kurma sürecinde olan girişimcilerdir. Bir iş fırsatını aktif olarak aramak, iş planı hazırlamak, internet araştırması yapmak gibi somut kurumsal yaratım faaliyetleri ile ilgilidirler. Potansiyel turizm girişimcileri ile eş anlamlı değildir. Doğmakta olan girişimciler bir turizm işletmesi oluşturma sürecinde iken, potansiyel girişimciler bir turizm işletmesi kurmayı eyleme geçirmemiş bireylerdir.

Farklı sebepler ile birlikte birden fazla turistik işletme kuran girişimcilerdir. Başarılı kısmı aktif olmalarından kaynaklı olarak toplum tarafından istenilen girişimcilerdir.

Kaynak: Koh ve Hatten, 2002: 33-39'den uyarlanmıştır.

Ürün farklılaşmasına göre turizm girişimcileri ise Tablo 3'de gösterildiği gibidir: 


\section{Tablo 3: Ürün Farklılaşmasına Göre Turizm Girişimcileri}

\section{Yaratıcı turizm girişimcisi (the Inventive tourism enterpreneur)}

Yenilikçi turizm girişimcisi (the innovative tourism enterpreneur)

Taklitçi turizm girişimcisi (imitative tourism enterpreneur)
Seyahat ve turizm sektörüne yeni bir teklif sunan girişimcilerdir. Thomas Cook'un daha öncesinde hiç olmayan kendi tur acentesini kurması buna örnek verilebilir.

Hizmetlere yenilik öneren girișimciler için kullanılır. Disneyland'ın yaratılması eğlence parklarına yenilik yapılarak ortaya çıkmıştır. Yaratıcı turizm girişimcilerine göre çok daha az risk taşımaktadırlar. Çünkü, sunduğu fikirler az da olsa daha önce bilinen fikirlerdir.

Mevcut işletmelerin hizmetlerinden farkı bulunmamaktadır. Motel, lunapark, lokanta, kafe vb. üzerine işletme açan turizm girişimcileri için kullanılır. Franchise de bu kategoriye aittir.

Kaynak: Koh ve Hatten, 2002: 33-39'den uyarlanmıştır.

Turizm endüstrisinin sürdürülebilirliği, büyümesi ve gelişmesi konularında önemli bir uzun vadeli hükümet desteği, kapsamlı eğitim, araştırma ve planlama süreçleri gerekli olmaktadır (Nongsiej ve Shimray, 2017: 8). Bunun yanı sıra turizm girişimciliğine daha kolaylaştırıcı veya engelleyici olup olmadığının belirlemesi gereken konular ise; bir toplumun mevcut sosyo-kültürel, fiziki, ekonomik, düzenleyici ve lojistik ortamlarıdır. Turizm girişimcileri, hem bölgedeki yerel topluluklar ve geleneklerle yakın ilişki kurar, hem de bir yandan da denge sağlayarak yerel kaynakları yüksek kaliteli turizm ürün ve hizmetleri olarak sunabilmektedir. Turizm girişimciliğinin, sosyal, ekonomik ve politik koşulların bir motivasyon gücü olarak hizmet verdiği alanlarda gelişim gösterdiğine inanılmaktadır. Bu sebeple de toplum ve yönetim organlarınca desteklenmesi gereken bir konudur (Rusu vd., 2012: 25-26; Hollick ve Braun, 2005: 3).

\section{Yöntem}

Cittaslow olma yoluna giren Akçakoca ilçesinde kırsal turizm kapsamında değerlendirilebilecek alanlarda faaliyet gösteren turizm girişimcilerinin belirlenmesi ve bu bağlamda bölgesel kalkınmaya sağladığı katkıları hakkında detaylı verilere ulaşmak amacıyla nitel araştırma yapılması uygun görülmüştür. Nitel veri toplama yöntemlerinden gözlem, görüşme ve doküman analizinin kullanılarak, algı ve olayların doğal ortamlarında gerçekçi ve bütüncül olarak ortaya çıkarılmasına ilişkin nitel bir sürecin yürütüldüğü araştırmalar nitel araştırma olarak tanımlanabilir (Yıldırım ve Şimşek, 2005: 39). Turizm potansiyeline sahip bölgelerde, turizm sektöründe yapılmış yatırımların o bölge için önem arz etmesi sebebiyle, bu çalışma turizm sektöründe faaliyette bulunan girişimcilerin tespit edilmesi ve bölgesel kalkınmaya katkısının belirlenmesi açısından öneme sahiptir.

\subsection{Araştırmanın Evreni ve Örneklemi}

Araştırmanın evreni Akçakoca ilçesi olarak ele alınmıştır. Akçakoca, doğaya dayalı birçok alternatif turizm faaliyetinin gerçekleştirildiği bir turizm destinasyonu olarak bilinmektedir (Dağlı, 2018: 604). Bu araştırmada kasti (kararsal) örnekleme tekniği seçilmiştir. Akçakoca'da turizm girişimcilerinin bölgesel kalkınmadaki rollerinin belirlenmesine yönelik yapılan bu çalışmada araştırmacının kararı ile araştırma problemine cevap bulunulacağına inanılan 18 turizm girişimcisi örnekleme dâhil edilmiştir. Kırsal turizm kapsamında değerlendirilebilecek alanlarda faaliyette bulunan turizm girişimcilerinin seçilme sebebi ise Akçakoca ilçesinin doğal ve kırsal alanlarında turizm destinasyonu oluşturabilecek potansiyeli taşıması ve gelişmeye açık olmasıdır. Turizm girişimcilerinin işletmeleri, kırsal turizm kapsamında değerlendirilebilecek alanlarda faaliyette olan işletmelerdir. Bu işletmelerin ortak özellikleri ise yiyecek- 
içecek veya konaklama faaliyetlerinden herhangi birini barındırmasıdır. Araştırma, Akçakoca ilçesinde kırsal turizm kapsamında değerlendirilebilecek alanlarda turizm girişimciliğinde bulunan girişimciler ile sınırlıdır. Araştırmanın diğer bir sınırlılığı, araştırmaya dâhil edilecek iki turizm girişimcisinin belirli sebeplerden dolayı görüşmeyi kabul edememesidir.

\subsection{Araştırmanın Veri Toplama Süreci}

Çalışmada, Düzce Üniversitesi Sosyal ve Beşeri Bilimler Bilimsel Araştırma ve Yayın Etiği Kurulu'na başvuruda bulunulmuştur. Yayın Etiği Kurulu'nun planlanan araştırma sürecinin etik olarak uygun olduğuna dair kararı çalışmanın sonudan yer almaktadır. Bu araştırmada nitel araştırma yöntemi kapsamında, katılımcıların araştırma konusuna yönelik görüşlerinin alınması amacıyla yarı yapılandırılmış görüşme tekniği seçilmiştir. Veriler 18 turizm girişimcisi ile 09.02.2019-13.02.2019 tarihleri arasında yapılan görüşmeler ile elde edilmiştir. Görüşmeler 14 katılımcı ile kendi işletmesinde, 4 katıımcı ile de farklı bir mekânda gerçekleştirilmiştir. Seçilen katılımcılar ile gerçekleştirilen görüşmeler yaklaşık 10-45 dakika arası zaman dilimlerinde gerçekleştirilmiştir. Ses kayıt cihazı kullanılarak görüşmeler kaydedilmiş, önemli noktalar ise yazılarak not edilmiştir. Katılımcılardan açık ve anlaşılır yanıtlar alınmadığı durumlarda, sorular tekrar açıklanarak sorulmuştur. Ayrıca görüşme formunda aynı konu dâhilinde giden sorular, katılımcılara karışık düzende değiştirilerek yöneltilmiştir. Bunun sonucunda katılımcılardan daha geniş kapsamlı verilerin alınması sağlanmıştır. Turizm girişimcilerinin bölgesel kalkınmadaki rollerinin belirlenmesi amacıyla hazırlanan görüşme formu, ilgili literatür dikkate alınarak oluşturulmuştur. Görüşme formunda 15 adet açık uçlu soru yer almaktadır. Görüşme soruları oluşturulduktan sonra uzman iki akademisyenin değerlendirme ve görüşlerine başvurulmuştur. Bu bağlamda işletme sahibi turizm girişimcilerine aşağıdaki sorular yöneltilmiştir.

\section{Tablo 4: Görüşme Soruları}

1. Sizi turizm alanında girişimciliğe yönelten nedenler nelerdir?

2. İşletme kurarken örnek aldığınız bir işletme ya da işletmeler oldu mu? İşletme yerini ve sunduğunuz hizmet türünü seçerken öne çıkan faktörler nelerdir?

3. İşletmenizde yöreye özgü yiyecek ve içeceklerin sunumu ve satışı yapılıyor mu?

4. Çalış̧ııılan personelleriniz bölge içinden mi bölge dışından mı seçiliyor? Sezon içi ve yoğun dönemlerde istihdam oranı değişiyor mu?

5. İşletmenin ihtiyaçları bölge içinden mi bölge dışından mı temin ediliyor?

6. İşletmeniz mevsimsellik sorunundan etkileniyor mu? Yılın her ayı hizmet veriyor musunuz?

7. İşletmenize yönelik tanıtım ve reklam yapıyor musunuz, bunlar hangi faaliyetleri kapsıyor? Bu faaliyetler ziyaretçilerin gelme oranına nasıl etki ediyor?

8. İşletmenize gelen ziyaretçiler daha çok nereden geliyor?

9. İşletmenizde müşterilerinize yenilikçi fikirler kapsamında geliştirdiğiniz ürün ya da hizmet bulunuyor mu?

10. Turizm girişimciliğinin arttıılımasına yönelik neler yapılabilir? Turizm girişimciliğinin gelişmesi kapsamında yerel yönetimler size destek oluyor mu, bu bağlamda bölgede girişimciliği teşvik etmek için eğitim ya da destek sağlıyor mu?

11. Turizm alanında yapılan girişimlerin bölgeyi ziyaret eden turistler üzerinde nasıl bir etki oluşturduğunu düşünüyorsunuz?

12. Turizm alanında girişimcilikte bulunmanız sizce bölgedeki kültürel ve sosyal aktivite imkânlarını nasıl etkiliyor? Bu aktiviteleri arttırdığını düşünüyor musunuz?

13. Akçakoca'nın altyapı ve üstyapı imkânları sizi nasıl etkiliyor?

14. Akçakoca'da turizm girişimciliğinin artmasını tehdit eden unsurlar olduğunu düşünüyor musunuz?

15. Akçakoca'da turistik unsurlar (doğal, kültürel, toplumsal, yapay çekicilikler) yeterince değerlendirilebiliyor mu? Size katkısı ne açıdan oluyor? 


\subsection{Araştırma Verilerinin Analizi}

$\mathrm{Bu}$ araştırmanın veri analizinde nitel veri analiz tekniklerinden yararlanılmıştır. Bölgesel kalkınmada turizm girişimciliğinin rolü üzerine katılımcı görüşlerinden elde edilen verilerin çözümlenmesinde içerik analizi kullanılmıştır. $\mathrm{Bu}$ analiz, dokümanların, mülakata ait dökümlerin veya kayıtların karakterize edilmesinde ve karşılaştırılmasında kullanılmaktadır (Coşkun vd., 2015: 324). Toplanan verilerin açıklamasında yardımcı olacak kavram ve ilişkilere ulaşmak içerik analizinin temel amacıdır. Bu analizde yapılan işlem, belirlenen kavram ve temalar altında birbirine benzeyen verilerin toplanarak bir araya getirilmesi ve okuyanların anlamasını kolaylaştıracak bir şekilde bir düzen halinde yorumlanmasıdır (Karataş, 2017: 79).

Elde edilen bulgular tablolara aktarılıp, veriler üzerinde kodlama yapılarak, belirlenen kodlardan kategoriler ve temalar oluşturulmuştur. Temalar kapsadığı kodlarla bağlantılı olarak yorumlanmış ve sonuçlar ortaya konmuştur. Bulguların desteklenmesi adına katıımcıların ifadeleri alıntı olarak eklenmiştir.

\section{Bulgular}

Çalışmaya yönelik bulgular, turizm girişimcilerinin demografik bilgilerini, işletmeye ait bilgilerini ve araştırmaya ilişkin yöneltilen 15 soru ile ilgili düşünce ve değerlendirmelerini içermektedir. Araştırmada, gizliliğinin korunması amacıyla katılımcı isimleri K1, K2, K3 gibi harf ve sayılarla kodlanmıştır. Görüşme yapılan turizm girişimcilerine ait demografik bilgiler Tablo 5 'te bulunmaktadır.

Tablo 5: Katılımcılara Ait Demografik Bilgiler

\begin{tabular}{|c|c|c|c|c|c|c|}
\hline Kod & Cinsiyet & Yaş & $\begin{array}{l}\text { Medeni } \\
\text { Durum }\end{array}$ & $\begin{array}{l}\text { Eğitim } \\
\text { Durumu }\end{array}$ & $\begin{array}{l}\text { Önceki İş } \\
\text { Tecrübesi }\end{array}$ & $\begin{array}{l}\text { Turizm Sektöründe } \\
\text { Çalışılan Süre }\end{array}$ \\
\hline$\overline{\mathrm{K} 1}$ & Erkek & 50 & Evli & İlkokul & Şoför & $5 \mathrm{yll}$ \\
\hline K2 & Erkek & 55 & Evli & Lise & İşçi & $3 \mathrm{yıl}$ \\
\hline K3 & Erkek & 38 & Evli & Lisans & Mühendis & $1 \mathrm{yll}$ \\
\hline K4 & Erkek & 40 & Evli & Lise & Futbolcu & $8 \mathrm{yıl}$ \\
\hline K5 & Erkek & 42 & Evli & Lisans & Mühendis & $2 \mathrm{yll}$ \\
\hline K6 & Erkek & 55 & Evli & İlkokul & Çiftçi & $12 \mathrm{yll}$ \\
\hline K7 & Erkek & 41 & Evli & Lisans & Turizmci & $19 \mathrm{yıl}$ \\
\hline K8 & Erkek & 42 & Evli & İlkokul & Esnaf & 4 yıl \\
\hline K9 & Erkek & 35 & Bekâr & Lise & İşletmeci & $16 \mathrm{yıl}$ \\
\hline K10 & Kadın & 41 & Evli & İlkokul & Hayvancılık & 3 yıl \\
\hline K11 & Kadın & 48 & Evli & Lise & Tekstil & $3 \mathrm{yll}$ \\
\hline K12 & Erkek & 31 & Bekâr & Lisans & İşletmeci & $6 \mathrm{yll}$ \\
\hline K13 & Erkek & 60 & Evli & Lise & Muhasebeci & $20 \mathrm{yll}$ \\
\hline K14 & Erkek & 26 & Bekâr & Lise & Turizmci & 5 yıl \\
\hline K15 & Erkek & 33 & Evli & Lisans & Bankacı & $16 \mathrm{yll}$ \\
\hline K16 & Erkek & 68 & Evli & Lise & İşçi & $31 \mathrm{yıl}$ \\
\hline K17 & Erkek & 52 & Evli & Lise & Memur & 2 yıl \\
\hline K18 & Erkek & 57 & Evli & Lise & Esnaf & 19 yıl \\
\hline
\end{tabular}

Görüşülen kişilerin yaş aralığı 26 ile 68 arasında değişmekte ve 16 katılımcının 31 yaş üzeri olduğu görülmektedir. Katılımcıların 16'sı erkek ve medeni durumu evlidir. 9 katılımcının eğitim durumu lise, 5 katılımcının lisans derecesindedir. Daha önceki iş tecrübeleri ve meslekleri farklılık göstermektedir. Genel olarak turizm sektöründe 
çalıştıkları süreleri incelendiğinde ise en az 1 yıl en fazla 31 yıl olarak değiştiği görülmektedir. Bu bilgilere ek olarak araştırmaya katılan bireylerin tamamının yerel girişimci olduğu sonucuna ulaşılmıştır. Demografik bilgileri verilen katılımcıların işletmelerine yönelik bilgiler ise Tablo 6 'da bulunmaktadır.

Tablo 6: Katılımcıların İşletmelerine Ait Bilgiler

\begin{tabular}{|c|c|c|c|c|c|}
\hline Kod & $\begin{array}{l}\text { Hukuki } \\
\text { Türü }\end{array}$ & $\begin{array}{l}\text { Sahiplik } \\
\text { Durumu }\end{array}$ & $\begin{array}{l}\text { İşletmenin } \\
\text { Faaliyet } \\
\text { Süresi }\end{array}$ & $\begin{array}{l}\text { Personel } \\
\text { Sayısı }\end{array}$ & Faaliyet Alanları \\
\hline K1 & Tek kişi & Mülk sahibi & $5 \mathrm{yll}$ & Yaz: 3 & $\begin{array}{c}\text { Konaklama/Yiyecek-İcecek } \\
\text { Eğlence/Rekreasyon }\end{array}$ \\
\hline K2 & Tek kişi & Mülk sahibi & $3 \mathrm{yll}$ & $\begin{array}{l}\text { Yaz:1-2 } \\
\text { Part time }\end{array}$ & $\begin{array}{c}\text { Konaklama/Yiyecek-íçecek } \\
\text { Toplantı/Eğlence }\end{array}$ \\
\hline K3 & Tek kişi & Mülk sahibi & $1 \mathrm{yll}$ & 10 & $\begin{array}{c}\text { Yiyecek-İcecek/Eğlence } \\
\text { Rekreasyon }\end{array}$ \\
\hline K4 & Tek kişi & Kira & $5 \mathrm{yll}$ & $\begin{array}{l}\text { Yaz: } 8 \\
\text { Kış: } 4\end{array}$ & Yiyecek-l̇çecek/Eğlence \\
\hline K5 & Ortaklık & Kira & 2 yıl & $\begin{array}{l}\text { Yaz: } 30 \\
\text { Kış: } 4\end{array}$ & $\begin{array}{c}\text { Konaklama/Yiyecek-i̇çecek } \\
\text { Eğlence }\end{array}$ \\
\hline K6 & Tek kişi & Kira & $12 \mathrm{yll}$ & Yaz: 3-4 & Yiyecek-İçecek \\
\hline K7 & Tek kişi & Mülk sahibi & 6 ay & 1 & Yiyecek-İçecek/Eğlence \\
\hline K8 & Tek kişi & Kira & 4 yıl & - & $\begin{array}{c}\text { Yiyecek } \\
\text { İcecek/Rekreasyon }\end{array}$ \\
\hline K9 & Tek kişi & Mülk sahibi & 15 yıl & $\begin{array}{l}\text { Yaz: 8-10 } \\
\text { Kış: } 3-5\end{array}$ & Yiyecek-İçecek \\
\hline K10 & Tek kişi & Mülk sahibi & $4 \mathrm{yll}$ & $\begin{array}{l}\text { Yaz: } 10 \\
\text { Kış: } 1\end{array}$ & Yiyecek-İçecek \\
\hline K11 & Tek kişi & Kira & 3 yıl & $\begin{array}{l}\text { Yaz: } 6 \\
\text { Kış: } 3-4\end{array}$ & Yiyecek-i̇çecek \\
\hline K12 & Tek kişi & Mülk sahibi & $6 \mathrm{yıl}$ & 2 & Konaklama \\
\hline K13 & Tek kişi & Mülk sahibi & $14 \mathrm{yll}$ & $\begin{array}{l}\text { Yaz: } 15 \\
\text { Kış: } 3\end{array}$ & Yiyecek-İçecek \\
\hline K14 & Tek kişi & Mülk sahibi & $1 \mathrm{yll}$ & $\begin{array}{l}\text { Yaz: } 4-5 \\
\text { Kış: } 2\end{array}$ & Konaklama/Yiyecek-İçecek \\
\hline K15 & Tek kişi & Mülk sahibi & 16 yıl & 4 & Yiyecek-İçecek \\
\hline K16 & Tek kişi & Mülk sahibi & $31 \mathrm{yıl}$ & - & $\begin{array}{c}\text { Konaklama/Yiyecek-ìçecek } \\
\text { Eğlence }\end{array}$ \\
\hline K17 & Tek kişi & Mülk sahibi & $2 \mathrm{yll}$ & $\begin{array}{l}\text { Yaz: } 2-3 \\
\text { Kış: } 1\end{array}$ & $\begin{array}{c}\text { Yiyecek-İçecek/Eğlence } \\
\text { Toplantı }\end{array}$ \\
\hline K18 & Ortaklık & Kira & 19 yıl & $\begin{array}{l}\text { Yaz: } 40-45 \\
\text { Kış: } 18 \\
\end{array}$ & Konaklama/Yiyecek-l̇çecek \\
\hline
\end{tabular}

Görüşülen kişilerin işletmeleri çoğunluk olarak tek kişi olarak kurulmuş olup, mülk sahipliği bulunmaktadır. İşletmelerin faaliyet süreleri en az altı ay ve en fazla 31 yıl olarak değişmektedir. Çalıştırılan personel sayısı incelendiğinde en az bir kişi ve en fazla 40-45 kişi olarak değiştiği görülmekte ve sezonlara göre bu rakamların değişkenlik gösterdiği anlaşılmaktadır. Buna ek olarak iki katılımcının hiç personel çalıştırmadığı, ihtiyaç olduğu durumlarda aile veya arkadaş çevresinden karşılandığı sonucuna ulaşılmıştır. Faaliyet alanları incelendiğinde beş işletme sadece yiyecekiçecek hizmeti, bir işletme sadece konaklama hizmeti vermektedir. Diğerlerinin ise ya sadece konaklama ve yiyecek-içecek hizmeti vermekte ya da bunlardan biri veya 
ikisinin yanında eğlence organizasyonları, toplantı organizasyonları ve rekreasyon aktiviteleri hizmeti de vermekte olduğu görülmektedir.

\subsection{Katılımcıları Turizm Girişimciliğine Yönelten Nedenlere İlişkin Bulgular}

Katılımcıları turizm girişimciliğine yönelten nedenlere ilişkin kod ve temalar Tablo 7'de sunulmuştur.

Tablo 7: Turizm Girişimciliğine Yönelten Nedenler

\begin{tabular}{ll|l}
\hline Tema & Kod ve Kategoriler & Katılımcılar \\
\hline \multirow{3}{*}{ Nedenler } & \begin{tabular}{l} 
Genel Nedenler \\
\cline { 2 - 3 }
\end{tabular} & \\
\cline { 2 - 3 } & Mevcut olan alanın değerlendirilmesi & $\mathrm{K} 3, \mathrm{~K} 9, \mathrm{~K} 10, \mathrm{~K} 12, \mathrm{~K} 14, \mathrm{~K} 15$ \\
\cline { 2 - 3 } & Maddi kazanç elde edilebilmesi & $\mathrm{K} 1, \mathrm{~K} 11, \mathrm{~K} 12$ \\
\cline { 2 - 3 } & $\begin{array}{l}\text { Akçakoca İle İlgili Nedenler } \\
\text { Akçakoca'da olmayan bir şeyin yapılması }\end{array}$ & $\mathrm{K} 6, \mathrm{~K} 7, \mathrm{~K} 8, \mathrm{~K} 14, \mathrm{~K} 18$ \\
\cline { 2 - 3 } & $\begin{array}{l}\text { Akçakoca'nın turizminin gelişmesine katkı } \\
\text { sağlanması }\end{array}$ & $\mathrm{K} 2, \mathrm{~K} 4, \mathrm{~K} 5, \mathrm{~K} 16, \mathrm{~K} 17$ \\
\cline { 2 - 3 } & Akçakoca'nın bu işe potansiyelinin olması & $\mathrm{K} 12, \mathrm{~K} 13$ \\
\hline
\end{tabular}
şekildedir:

Katılımcıları turizm girişimciliğine yönelten nedenlere yönelik ifadeler şu

K3:"Turizm tesisi yaptığımız yer atalarımızdan kalmaydı. Çocukluk hayalim olan eskiden beri burada şöyle bir şey olsa diye düşündüğüm şeyleri ve dışarılarda harcadığım vakitlerde olan birikimleri birleştirince böyle bir şey çıktı ortaya. İçinde at çiftliği, gece eğlenceleri ve diğer rekreasyon aktivitelerini barındıran turistik bir tesis."

K4:"Memleketimizin turizmini nasıl geliştirebiliriz ve bunu nasıl yapabiliriz çalışmalarıyla uğraştık. Akçakoca'yı çok iyi tanıdığım için farklı yerlerde tabi ki işlerimizle ilgili çok çalışmalar yaptık. Yerleri tespit ederken de ön araştırmalar yaptık. Ayrıca işletmede doğaya açılmak ilk hedefimdi."

K12:"Öncelikle yer ile ilgili böyle bir imkânımın olması, Akçakoca'nın bu işe potansiyelinin açık olması ve son olarak da çevremden bir kişinin vesile olması."

\subsection{Katılımcıların İşletme Kurarken Örnek Aldığı Bir İşletme Olup OImadığına ve İşletme Yerini ve Sunulan Hizmet Türünü Seçerken Öne Çıkan Faktörlere İlişkin Bulgular}

Katılımcıları işletme kurarken örnek aldığı bir işletme olup olmadığına ve işletme yerini ve sunulan hizmet türünü seçerken öne çıkan faktörlere ilişkin kod ve temalar Tablo 8 'de sunulmuştur. 
Tablo 8: Katılımcıların İşletme Kurarken Örnek Aldığı Bir İşletme Olup Olmadığına ve İşletme Yerinin ve Sunulan Hizmet Türünün Seçilmesine İlişkin Öne Çıkan Faktörler

\begin{tabular}{|c|c|c|}
\hline \multicolumn{2}{|c|}{ Tema Kod ve Kategoriler } & Katılımcılar \\
\hline \multirow{3}{*}{$\begin{array}{l}\text { Örnek alınan } \\
\text { bir işletme } \\
\text { olup olmadığı }\end{array}$} & $\begin{array}{l}\text { Örnek alınan bir işletmenin olduğuna } \\
\text { yönelik }\end{array}$ & $\begin{array}{l}\mathrm{K} 1, \mathrm{~K} 3, \mathrm{~K} 5, \mathrm{~K} 6, \mathrm{~K} 8, \mathrm{~K} 9, \mathrm{~K} 11, \mathrm{~K} 12, \mathrm{~K} 1 \\
4, \mathrm{~K} 16, \mathrm{~K} 17\end{array}$ \\
\hline & Diğer bölgelerden & $\mathrm{K} 1, \mathrm{~K} 3, \mathrm{~K} 5, \mathrm{~K} 8, \mathrm{~K} 9, \mathrm{~K} 11, \mathrm{~K} 14, \mathrm{~K} 17$ \\
\hline & 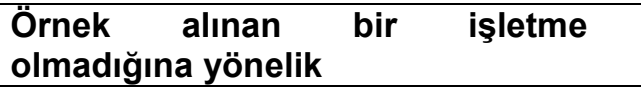 & $\mathrm{K} 2, \mathrm{~K} 4, \mathrm{~K} 7, \mathrm{~K} 10, \mathrm{~K} 13, \mathrm{~K} 15, \mathrm{~K} 18$ \\
\hline \multirow{10}{*}{$\begin{array}{l}\text { Seçiminde } \\
\text { öne çıkan } \\
\text { faktörler }\end{array}$} & $\begin{array}{l}\text { İşletme yeri seçiminde öne çıkan } \\
\text { faktörler } \\
\text { Kendine ait bulunan bir alanın olması }\end{array}$ & $\mathrm{K} 1, \mathrm{~K} 2, \mathrm{~K} 3, \mathrm{~K} 9, \mathrm{~K} 10, \mathrm{~K} 12, \mathrm{~K} 14, \mathrm{~K} 15$ \\
\hline & Doğaya ve denize yakınlık & $\mathrm{K} 4, \mathrm{~K} 5, \mathrm{~K} 7, \mathrm{~K} 12, \mathrm{~K} 13, \mathrm{~K} 14, \mathrm{~K} 18$ \\
\hline & Merkeze yakınlık & K7 \\
\hline & Dere kenarında olması & K7 \\
\hline & Hizmete uygun olan bir alan olması & $\mathrm{K} 6, \mathrm{~K} 16, \mathrm{~K} 17$ \\
\hline & Turistik alanlardan birine yakın olunması & $\mathrm{K} 8, \mathrm{~K} 11, \mathrm{~K} 13$ \\
\hline & $\begin{array}{l}\text { Hizmet türü seçiminde öne çıkan } \\
\text { faktörler } \\
\text { Akçakoca'da böyle bir tesisin eksikliği }\end{array}$ & $\mathrm{K} 2, \mathrm{~K} 4, \mathrm{~K} 5, \mathrm{~K} 6, \mathrm{~K} 12, \mathrm{~K} 16, \mathrm{~K} 18$ \\
\hline & $\begin{array}{l}\text { Akçakoca'da olmayan bir şeyin } \\
\text { yapılması isteği }\end{array}$ & $\mathrm{K} 3, \mathrm{~K} 7, \mathrm{~K} 8, \mathrm{~K} 9, \mathrm{~K} 14$ \\
\hline & $\begin{array}{l}\text { Bu işe yatkın olunması ve iyi yaptığına } \\
\text { olan inancı }\end{array}$ & $\mathrm{K} 1, \mathrm{~K} 10, \mathrm{~K} 11, \mathrm{~K} 13, \mathrm{~K} 14, \mathrm{~K} 17$ \\
\hline & Miras kalması & K15 \\
\hline
\end{tabular}

Katılımcıların bazılarının ifadeleri şu şekildedir:

K7:"Işletme kurarken örnek aldığımız değil de sadece Akçakoca'da bu ihtiyaca göre bu tesisi kurmaya çalıştık. Akçakoca'da çocuklarımızla vakit geçirebilecek bir yere gidemiyorduk. Ona istinaden biz de çocukların eğlenebileceği, yeşil alanı bol olan, daha önceden aldığımız bu alanı bu şekilde değerlendirdik. Konsept ve dizayn olarak Ankara'da bir işletmede beğendiğim şeyleri yapmaya çalıştım. İşletme yerinin seçiminde merkeze yakın olması, dere kenarı olması ve yeşilliğin içinde olması temel faktörlerdendi. Hizmet türü de tamamen aileye yönelik bir yer olması, bizim de kendi ihtiyaçlarımızı burada karşılayacağımız ve Akçakoca'da böyle bir tesisin olmaması cezbetmişti diyebilirim."

K14:"Örnek aldığım birçok işletmeyi gezerek gördüm. Yani bungalov olarak Karadeniz bölgesinde ve Bolu'da bütün tesisleri gezip gördüm. Özellikle kendi arazim olduğu için ben bu yeri seçtim. Dışarıda bir arazi almayı düşünseydim buraya yapmazdım. Çevreye yakın olmamız, kendi arazimiz olması, bu işe yatkın olmamız ve Akçakoca'da böyle bir işletmenin olmaması öne çıkan faktörler diyebilirim."

\subsection{Katılımcıların İşletmelerinde Yöreye Özgü Yiyecek ve İçecek Sunumunun veya Satışının Yapılıp Yapılmadığına İlişkin Bulgular}

Yöreye özgü yiyecek ve içecek sunumu veya satışına ilişkin kod ve temalar Tablo 9'da sunulmuştur. 
Tablo 9: Yöreye Özgü Yiyecek ve İçecek Sunumu veya Satışı

\begin{tabular}{|c|c|c|}
\hline Tema & Kod ve Kategoriler & Katılımcılar \\
\hline \multirow{4}{*}{$\begin{array}{c}\text { Yöreye özgü } \\
\text { yiyecek ve içecek } \\
\text { sunumu veya } \\
\text { satışı }\end{array}$} & Yapıldığına yönelik & $\begin{array}{l}\mathrm{K} 1, \mathrm{~K} 2, \mathrm{~K} 6, \mathrm{~K} 7, \mathrm{~K} 10, \mathrm{~K} 11, \mathrm{~K} 13, \\
\mathrm{~K} 15, \mathrm{~K} 17, \mathrm{~K} 18\end{array}$ \\
\hline & $\begin{array}{l}\text { Yapıldığı ancak diğerlerine göre } \\
\text { daha az olduğu }\end{array}$ & $\mathrm{K} 3, \mathrm{~K} 4, \mathrm{~K} 5$ \\
\hline & Yapılmadığına yönelik & $\mathrm{K} 9, \mathrm{~K} 12, \mathrm{~K} 16$ \\
\hline & $\begin{array}{l}\text { Yapılmadığı ancak yapılacağına } \\
\text { yönelik }\end{array}$ & $\mathrm{K} 8, \mathrm{~K} 14$ \\
\hline
\end{tabular}

Yöreye özgü yiyecek ve içecek sunumunun veya satışının yapılıp yapılmadığına ilişkin bir katıımcının ifadesi şöyledir:

K11:"Mancarlı pide, Melengüççeği, Laz böreği, mantı, makarna çeşitleri, yöresel kahvaltı, dolma vb. yiyeceklerin sunumunu yapıyoruz. Ama satış olarak makarna gibi şeyleri kilo ile satmıyorum. Sadece Melengüççeği veya Laz böreği götürmek isteyen olursa satıyorum."

\subsection{Katılımcıların İşletmelerinde Çalıştırılan Personellere İlişkin Bulgular}

Katılımcıların işletmelerinde çalıştırılan personellere ilişkin kod ve temalar Tablo 10'da sunulmuştur.

Tablo 10: Katılımcıların İşletmelerinde Çalıştırılan Personellere Yönelik Bilgiler

\begin{tabular}{cl|l}
\hline Tema & Kod ve Kategoriler & Katılımcılar \\
\hline \multirow{2}{*}{$\begin{array}{c}\text { Personel } \\
\text { seçimi }\end{array}$} & $\begin{array}{l}\text { Personel çalıştırdığına } \\
\text { yönelik }\end{array}$ & $\begin{array}{l}\mathrm{K} 1, \mathrm{~K} 2, \mathrm{~K} 3, \mathrm{~K} 4, \mathrm{~K} 5, \mathrm{~K} 6, \mathrm{~K} 7, \mathrm{~K} 9, \mathrm{~K} 10, \\
\mathrm{~K} 11, \mathrm{~K} 12, \mathrm{~K} 13, \mathrm{~K} 14, \mathrm{~K} 15, \mathrm{~K} 17, \mathrm{~K} 18\end{array}$ \\
\cline { 2 - 3 } & $\begin{array}{l}\text { Bölge içinden personel } \\
\text { çalıştırdığı }\end{array}$ & $\mathrm{K} 1, \mathrm{~K} 2, \mathrm{~K} 4, \mathrm{~K} 6, \mathrm{~K} 7, \mathrm{~K} 9, \mathrm{~K} 10, \mathrm{~K} 11, \mathrm{~K}$ \\
& $\begin{array}{l}\text { Hem bölge içinden hem } \\
\text { bölge dışından çalıştırdığı }\end{array}$ & $\mathrm{K} 3, \mathrm{~K} 5, \mathrm{~K} 13, \mathrm{~K} 18$ \\
\cline { 2 - 3 } & $\begin{array}{l}\text { Personel çalıştırmadığına } \\
\text { yönelik }\end{array}$ & $\mathrm{K} 8, \mathrm{~K} 16$ \\
\hline $\begin{array}{c}\text { Sezon içi ve yoğun } \\
\text { dönemlerde } \\
\text { istihdam oranı } \\
\text { değişimi }\end{array}$ & $\begin{array}{l}\text { İstihdam oranının } \\
\text { değiştiğine yönelik }\end{array}$ & $\mathrm{K} 1, \mathrm{~K} 2, \mathrm{~K} 3, \mathrm{~K} 4, \mathrm{~K} 5, \mathrm{~K} 6, \mathrm{~K} 7, \mathrm{~K} 9, \mathrm{~K} 10$, \\
\cline { 2 - 3 } $\begin{array}{l}\text { İstihdam oranının } \\
\text { değişmediğine yönelik }\end{array}$ & $\mathrm{K} 11, \mathrm{~K} 13, \mathrm{~K} 14, \mathrm{~K} 15, \mathrm{~K} 17, \mathrm{~K} 18$ \\
\hline
\end{tabular}
şekildedir:

İşletmelerinde çalıştırılan personellere yönelik iki katılımcının ifadesi şu

K3: "Teoride bakıldığı zaman en kaliteli elemanı nereden buluyorsan getireceksin bütün her şeyini sağlayacaksın. Ama pratikte öyle bir şey yok artık günü kurtarmak adına nereden personel buluyorsan onu çalıştırıyorsun. O bakımdan Yığılca ilçesinden de olabilir, Zonguldak'tan da olabilir, Akçakoca'dan da olabilir bir genelleme yok. Sezon içi ve yoğun dönemlerde 4 katına artabiliyor tabi personel sayısı."

K5:"Yatılı personeli genelde bölge dışından alıyoruz. Ama tercihimiz bölge içinden personel alabilmek. Çünkü yatılı personelin bir maliyeti oluyor. Maliyetli olduğu 
için genel de Akçakoca'dan seçmek tercihimiz. Yazın daha çok istihdam ediyoruz. Yazları 30 personel çalıştıırken, kışları 4 personel çalıştırıyoruz."

\subsection{Katılımcıların İşletme İhtiyaçlarını Bölge İçinden mi Bölge Dışından mı Temin Ettiğine İlişkin Bulgular}

Katılımcıların işletme intiyaçlarını nereden temin ettiklerine ilişkin kod ve temalar Tablo 11 'de sunulmuştur.

Tablo 11: Katılımcıların İşletme İhtiyaçlarını Nereden Temin Ettiğine Yönelik Bilgiler

\begin{tabular}{cl|l}
\hline Tema & Kod ve Kategoriler & Katılımcılar \\
\hline \multicolumn{1}{c}{$\begin{array}{c}\text { İşletme } \\
\text { intiyaçlarının } \\
\text { temini }\end{array}$} & $\begin{array}{l}\text { Bölge içinden temin edildiğine } \\
\text { yönelik }\end{array}$ & $\begin{array}{l}\mathrm{K} 1, \mathrm{~K} 2, \mathrm{~K} 3, \mathrm{~K} 4, \mathrm{~K} 6, \mathrm{~K} 7, \mathrm{~K} 10, \mathrm{~K} 11 \\
\mathrm{~K} 12, \mathrm{~K} 13, \mathrm{~K} 14, \mathrm{~K} 15, \mathrm{~K} 16, \mathrm{~K} 17\end{array}$ \\
\cline { 2 - 3 } & $\begin{array}{l}\text { Hem bölge içinden hem de bölge } \\
\text { dışından temin edildiğine yönelik }\end{array}$ & $\mathrm{K} 5, \mathrm{~K} 8, \mathrm{~K} 18$ \\
\cline { 2 - 3 } & $\begin{array}{l}\text { Bölge dişından temin edildiğine } \\
\text { yönelik }\end{array}$ & $\mathrm{K} 9$ \\
\hline
\end{tabular}
şekildedir:

İşletme intiyaçlarının nereden temin edildiğine yönelik iki katıımcının ifadesi şu

K1: "Çevreden ve yöresel pazardan eksikliklerimizi gidermeye çalışıyoruz. Yine yöresel pazardan köy ürünleri olarak almaya çalışıyoruz"

K11:"\%99 buranın ürünlerini kullanıyorum diyebilirim. Dışarıdan hiçbir şey almıyorum neredeyse. Cevize ihtiyacım oluyor komşumdan alıyorum, tavuğa ihtiyacım oluyor köyden alıyorum. Buradan tüketmeye çalışıyorum. Mobilyaya kadar burada yaptırıyoruz."

5.6. Katılımcıların İşletmelerinin Mevsimsellik Sorunundan Etkilenip Etkilenmediğine İlişkin Bulgular

Katılımcıların işletmelerinin mevsimsellik sorunundan etkilenip etkilenmediği ve yılın her ayı hizmet verip vermediğine yönelik kod ve temalar Tablo 12'de sunulmuştur.

Tablo 12: Katılımcıların İşletmelerinin Mevsimsellik Sorunundan Etkilenip Etkilenmediğine İlişkin Bilgiler

\begin{tabular}{ll|l}
\hline Tema & Kod ve Kategoriler & Katılımcılar \\
\hline $\begin{array}{l}\text { Mevsimsellik } \\
\text { sorunu }\end{array}$ & Etkilendiğine yönelik & Tüm katılımcılar \\
\hline \multirow{4}{*}{ Hizmet süresi } & $\begin{array}{l}\text { Yılın hangi ayları hizmet } \\
\text { verdiğine yönelik }\end{array}$ & \\
& Yılın her ayı hizmet verdiği & $\mathrm{K} 3, \mathrm{~K} 4, \mathrm{~K} 5, \mathrm{~K} 7, \mathrm{~K} 8, \mathrm{~K} 9, \mathrm{~K} 12, \mathrm{~K} 1$ \\
& & $3, \mathrm{~K} 14, \mathrm{~K} 15, \mathrm{~K} 17, \mathrm{~K} 18$ \\
\cline { 2 - 3 } & $\begin{array}{l}\text { Sadece hafta sonları olmak üzere } \\
\text { yılın her ayı hizmet verdiği }\end{array}$ & $\mathrm{K} 2, \mathrm{~K} 10, \mathrm{~K} 11$ \\
\cline { 2 - 3 } & Sadece yaz aylarında hizmet verdiği & $\mathrm{K} 1, \mathrm{~K} 6, \mathrm{~K} 16$ \\
\hline
\end{tabular}

Mevsimsellik sorununa yönelik iki katılımcının ifadesi şu şekildedir: 
K6:"Mevsimsellik sorunundan etkileniyor, biz yılın her ayı hizmet veririz ama gelen olmuyor. Çünkü yollarda bakım yok, yürüyüş yolu yok. Bu sebeple bu sene kış sezonu çalışmadık."

K8:"Mevsimsellik sorunundan etkileniyoruz. Yani bir yaz sezonu gibi olmuyor. Mesela kışın ya da diğer yağmurlu havalarda sadece kafe bölümüm çalışıyor. Ama yazın paintball sürekli dâhil oluyor. Genel olarak 12 ay hizmet veriyorum."

\subsection{Katılımcıların İşletmelerine Yönelik Tanıtım ve Reklam Yapıp Yapmadığına ve Ziyaretçilerin Gelme Oranına Etki Edip Etmediğine İlişkin Bulgular}

Katılımcıların işletmelerine yönelik tanıtım ve reklam yapıp yapmadığı, yapıyorlarsa bunların hangi faaliyetlerden oluştuğu ve bunların ziyaretçilerin gelme oranına etki edip etmediğine yönelik kod ve temalar Tablo 13'de sunulmuştur.

Tablo 13: Katılımcıların İşletmelerine Yönelik Tanıtım ve Reklam Faaliyetleri ve Gelme Oranına Etkileri

\begin{tabular}{|c|c|c|}
\hline Tema & Kod ve Kategoriler & Katılımcılar \\
\hline \multirow[t]{3}{*}{$\begin{array}{l}\text { Tanıtım ve } \\
\text { reklam } \\
\text { faaliyetleri }\end{array}$} & $\begin{array}{l}\text { Yapıldığına yönelik } \\
\text { (gazete, radyo, sosyal medya, } \\
\text { billboard, televizyon, internet, } \\
\text { kulüp üyeliği) }\end{array}$ & $\begin{array}{l}\mathrm{K} 3, \mathrm{~K} 4, \mathrm{~K} 5, \mathrm{~K} 6, \mathrm{~K} 7, \mathrm{~K} 8, \mathrm{~K} 9, \mathrm{~K} 10, \mathrm{~K} 1 \\
1, \mathrm{~K} 12, \mathrm{~K} 13, \mathrm{~K} 15, \mathrm{~K} 16, \mathrm{~K} 17, \mathrm{~K} 18\end{array}$ \\
\hline & Az yapıldığı & $\mathrm{K} 7, \mathrm{~K} 8, \mathrm{~K} 10, \mathrm{~K} 12, \mathrm{~K} 18$ \\
\hline & $\begin{array}{l}\text { Yapılmadığına yönelik } \\
\text { (gelen misafir aracılığıyla, } \\
\text { Akçakoca tanıtım sayfası) }\end{array}$ & $\mathrm{K} 1, \mathrm{~K} 2, \mathrm{~K} 14$ \\
\hline \multirow{2}{*}{$\begin{array}{l}\text { Ziyaretçilerin } \\
\text { gelme } \\
\text { oranına etkisi }\end{array}$} & Olumlu etki ettiğine yönelik & $\begin{array}{l}\mathrm{K} 1, \mathrm{~K} 2, \mathrm{~K} 3, \mathrm{~K} 4, \mathrm{~K} 5, \mathrm{~K} 7, \mathrm{~K} 8, \mathrm{~K} 9, \mathrm{~K} 10 \\
\text {,K11,K12,K15,K16,K17,K18 }\end{array}$ \\
\hline & $\begin{array}{l}\text { Hem olumlu hem de olumsuz etki } \\
\text { ettiğine yönelik }\end{array}$ & $\mathrm{K} 6$ \\
\hline
\end{tabular}

İşletmelerine yönelik tanıtım ve reklam faaliyetleri ve gelme oranına etkilerine ilişkin iki katıımcının ifadesi şu şekildedir:

K2:"Ben reklam yapmadım ve bunun misafirin görevi olduğunu düşünüyorum. Buraya gelen misafirin beni övmesi gerekli diye düşünüyorum. Ben oraya gittim çok güzel hizmet gördüm demesi, benim o reklama vereceğim ücretten daha fazla katkı sağlar bana. O yüzden reklam vermiyorum. Sadece Akçakoca tanıtım sayfalarında gözüküyorum."

K5:"Reklam yapıyoruz ve etkisi olduğunu düşünüyorum. Çok sayıda geri dönüşüm oluyor. Sosyal medya en büyük etkenlerden biri olmakla birlikte Instagram ve Facebook'ta reklam veriyoruz. Bunun dışında billboardlara da reklam veriyoruz."

\subsection{Katılımcıların İşletmelerine Ziyaretçilerin En Çok Nereden Geldiğine İlişkin Bulgular}

Görüşme gerçekleştirilen katılımcıların işletmelerine gelen ziyaretçilerin en çok nereden geldiklerine yönelik kod ve temalar Tablo 14'te sunulmuştur. 
Tablo 14: Katılımcıların İşletmelerine Gelen Ziyaretçi Profili

\begin{tabular}{ll|l}
\hline Tema & Kod ve Kategoriler & Katılımcılar \\
\hline \multirow{2}{*}{$\begin{array}{c}\text { Ziyaretçi } \\
\text { profili }\end{array}$} & Yerli & $\mathrm{K} 1, \mathrm{~K} 2, \mathrm{~K} 3, \mathrm{~K} 4, \mathrm{~K} 5, \mathrm{~K} 6, \mathrm{~K} 7, \mathrm{~K} 9, \mathrm{~K} 10, \mathrm{~K}$ \\
& & $11, \mathrm{~K} 12, \mathrm{~K} 13, \mathrm{~K} 14, \mathrm{~K} 15, \mathrm{~K} 17, \mathrm{~K} 18$ \\
\cline { 2 - 3 } & Bölge dışından & Tüm katılımcılar \\
\cline { 2 - 3 } & Hem yerli hem yabancı & $\mathrm{K} 8$ \\
\cline { 2 - 3 } & Yabancı & $\mathrm{K} 16$ \\
\hline
\end{tabular}

İşletmelerine gelen ziyaretçilerin en çok nereden geldiklerine yönelik iki katılımcının ifadesi şu şekildedir:

K1:"Yerli ziyaretçilerimiz geliyor. Bölge dışından ve bunlarda Ankara'dan oluyor genellikle. Çünkü İstanbul'dan buraya gelene kadar Yalova, Sapanca ve Şile gibi birçok seçenek olduğu için buraya gelmek biraz zorlaşıyor. Daha çok Karasu'ya geliyorlar. Ama Ankaralı ziyaretçilerin gidebileceği deniz kıyısı başka bir yer olmadığı için en yakın yer burası oluyor. Bu sebeple en çok Ankara'dan ziyaretçilerimiz geliyor."

K8: "Çoğunluk yerli oluyor. Çevre bölgelerden geliyorlar. Ayrıca yabancı olarak da Akçakoca Ak Resort Otel'e gelen Arap ziyaretçiler mutlaka buraya geliyorlar."

\subsection{Katılımcıların Ziyaretçilerine Yenilikçi Fikirler Kapsamında Geliştirdiği Ürün ya da Hizmetlere İlişkin Bulgular}

Ziyaretçilerine yenilikçi fikirler kapsamında geliştirdiği ürün ya da hizmetlerin varlığına yönelik kod ve temalar Tablo 15'te sunulmuştur.

Tablo 15: Katılımcıların Ziyaretçilerine Yenilikçi Fikirler Kapsamında Geliştirdiği Ürün ya da Hizmetler

\begin{tabular}{|c|c|c|}
\hline Tema & Kod ve Kategoriler & Katılımcılar \\
\hline \multirow[t]{2}{*}{$\begin{array}{l}\text { Yenilikçi ürün } \\
\text { ya da hizmet }\end{array}$} & $\begin{array}{l}\text { Geliştirdiği ürün ya da hizmetlerin } \\
\text { olduğu }\end{array}$ & $\begin{array}{l}\mathrm{K} 1, \mathrm{~K} 2, \mathrm{~K} 3, \mathrm{~K} 4, \mathrm{~K} 5, \mathrm{~K} 6, \mathrm{~K} 7, \mathrm{~K} 8, \mathrm{~K} 9, \mathrm{~K} 10, \mathrm{~K} 1 \\
1, \mathrm{~K} 13, \mathrm{~K} 14, \mathrm{~K} 15, \mathrm{~K} 16, \mathrm{~K} 17, \mathrm{~K} 18\end{array}$ \\
\hline & $\begin{array}{l}\text { Uygulama olarak olmadığı sadece } \\
\text { düşünce olarak olduğu }\end{array}$ & K12 \\
\hline
\end{tabular}

Ziyaretçilerine yenilikçi fikirler kapsamında geliştirdiği ürün ya da hizmetlere yönelik üç katılımcının ifadesi şu şekildedir:

K3:"Yiyecek olarak farklı yaptığımız bu bölgede yapılmayan bir yemek yapıyoruz. Aktivite olarak da seçeneklerimiz mevcut. Dere üzerinde yiyecek-içecek hizmeti imkânı sağlıyoruz. Kamelya kiralama ile kendin pişir kendin ye imkânı sağlıyoruz. Kır bahçesi organizasyon alanı, fasıl ve karaoke, havuzbaşı organizasyon alanı sağlıyoruz. Ayrıca mini çim saha, at ve eşek biniciliği, mini survivor, kayık ve bisiklet turları, zipline, mini golf-bowling, dere üzerinde salıncak gibi birçok yenilikçi fikirlerimiz mevcut bulunmakta. Bunların dışında bu yılın sonunda dağ oteli konseptinde konaklama da yapacağız."

K14:"Akçakoca'da benim bungalov tesisim gibi olan bir konaklama yeri yok. Restoran olsun bu şekilde yok. Hepsini kendim tasarlayarak yaptım. Evlerin içinde mutfak var fakat ayrıca restoran hizmeti de ekledim. Ayrıca yöresel ürünlerde satacağım." 
K18:"Antep mutfağını getirdik buraya. Akçakoca markası adı altında satılan fındıklı helva da aslında bizim ürünümüz. Karışımın patentini biz aldık yaklaşık 15 yıldır vermekteyiz. Dağıtım ağını çok geliştiremedik ama birkaç markette satışı yapılıyor."

\subsection{Turizm Girişimciliğinin Arttırılmasına Yönelik Neler Yapılabileceği ve Turizm Girişimciliğinin Gelişmesi Kapsamında Yerel Yönetimlerin Destek Olup Olmadığına İlişkin Bulgular}

Turizm girişimciliğinin arttırılması bağlamında neler yapılabileceğine, turizm girişimciliğinin gelişmesi kapsamında yerel yönetimlerin destek olup olmadığına ve bölgede girişimciliğin teşvik edilmesi için eğitim ya da destek sağlanıp sağlanmadığına yönelik kod ve temalar Tablo 16'da sunulmuştur.

Tablo 16: Turizm Girişimciliğinin Arttırılmasına Yönelik Neler Yapılabileceği ve Gelişmesi Kapsamında Yerel Yönetimlerin Destek Olup Olmadığına İlişkin Bulgular

\begin{tabular}{|c|c|c|}
\hline Tema & Kod ve Kategoriler & Katılımcılar \\
\hline \multirow{12}{*}{$\begin{array}{l}\text { Turizm } \\
\text { girişimciliğinin } \\
\text { arttırılmasına } \\
\text { yönelik neler } \\
\text { yapılabileceği }\end{array}$} & $\begin{array}{l}\text { Teşvik ve destek } \\
\text { Turizm girişimcilerine teşvik }\end{array}$ & $\mathrm{K} 1, \mathrm{~K} 10, \mathrm{~K} 14$ \\
\hline & $\begin{array}{l}\text { Turizme alternatif } \text { kazandıracak yerlerin } \\
\text { belirlenerek turizm girişimcilerinin teşvik } \\
\text { edilmesi }\end{array}$ & $\mathrm{K} 12, \mathrm{~K} 15, \mathrm{~K} 17$ \\
\hline & $\begin{array}{l}\text { Akçakoca'nın turizm } \\
\text { projelerine destek }\end{array}$ & $\mathrm{K} 5$, \\
\hline & Turizm mezunu kişilere destek & K7, \\
\hline & $\begin{array}{l}\text { Yerel yönetimlerin desteği ve yasak } \\
\text { koymaması }\end{array}$ & $\mathrm{K} 2, \mathrm{~K} 4, \mathrm{~K} 8, \mathrm{~K} 16$ \\
\hline & $\begin{array}{l}\text { Toplantı ve eğitim } \\
\text { Turizmle ilgili toplantılar }\end{array}$ & $\mathrm{K} 2$ \\
\hline & $\begin{array}{l}\text { İşletme sahiplerine ve esnaflara uzun süreli } \\
\text { eğitim }\end{array}$ & $\mathrm{K} 1, \mathrm{~K} 2$ \\
\hline & $\begin{array}{l}\text { Halkın Akçakoca'yı turizm alanı olarak } \\
\text { kavraması ve tanıtması }\end{array}$ & K3 \\
\hline & $\begin{array}{l}\text { Üniversite ile yönetimin diyalog halinde } \\
\text { olması ve okulun projeler üretip bunu finanse } \\
\text { edecek girişimcileri bulması }\end{array}$ & K7 \\
\hline & $\begin{array}{l}\text { Sorunların çözülmesi } \\
\text { Turistik değerlerin ön plana çıkarılması ve } \\
\text { sorunlarının çözülmesi }\end{array}$ & $\mathrm{K} 2, \mathrm{~K} 6$ \\
\hline & $\begin{array}{l}\text { Akçakoca'nın sorunlarının çözülmesi ve her } \\
\text { alana aynı özenin verilmesi }\end{array}$ & K11 \\
\hline & $\begin{array}{l}\text { Akçakoca'ya talebin arttırılması ve bunun } \\
\text { içinde festivallerin ve etkinliklerin yapılması }\end{array}$ & $\mathrm{K} 9, \mathrm{~K} 12, \mathrm{~K} 13, \mathrm{~K} 14$ \\
\hline \multirow{3}{*}{$\begin{array}{l}\text { Yerel yönetimlerin } \\
\text { destek olup } \\
\text { olmadığı }\end{array}$} & Desteğin olduğu & $\mathrm{K} 10, \mathrm{~K} 11, \mathrm{~K} 17$ \\
\hline & Desteğin olduğu fakat yeterli olmadığı & K4 \\
\hline & Desteğin olmadığı & $\begin{array}{l}\mathrm{K} 1, \mathrm{~K} 2, \mathrm{~K} 3, \mathrm{~K} 5, \mathrm{~K} 6, \mathrm{~K} 7, \mathrm{~K} 8, \mathrm{~K} 9, \\
\mathrm{~K} 12, \mathrm{~K} 13, \mathrm{~K} 14, \mathrm{~K} 15, \mathrm{~K} 16, \mathrm{~K} 18\end{array}$ \\
\hline \multirow{3}{*}{$\begin{array}{c}\text { Girişimciliğin } \\
\text { teşvik edilmesi } \\
\text { için eğitim ya da } \\
\text { destek }\end{array}$} & Sağlandığı & $\mathrm{K} 4, \mathrm{~K} 6, \mathrm{~K} 10, \mathrm{~K} 11, \mathrm{~K} 17$ \\
\hline & Sağlandığı fakat yeni olmadığı & K9 \\
\hline & Sağlanmadığı & $\begin{array}{l}\mathrm{K} 1, \mathrm{~K} 2, \mathrm{~K} 3, \mathrm{~K} 5, \mathrm{~K} 7, \mathrm{~K} 8, \mathrm{~K} 12, \mathrm{~K} \\
13, \mathrm{~K} 14, \mathrm{~K} 15, \mathrm{~K} 16, \mathrm{~K} 18\end{array}$ \\
\hline
\end{tabular}


Turizm girişimciliğinin arttırılmasına yönelik neler yapılabileceği ve gelişmesi kapsamında yerel yönetimlerin destek olup olmadığına ilişkin iki katılımcının ifadesi şu şekildedir:

K9:"Buraya bir talep olmalı ki girişimcilerde artsın. Bu talebin olması içinde bölgede festivallerin yapılması gerekmekte diye düşünüyorum. Eski doluluk Akçakoca'da kalmadı. Eskiden gelen bu işletmelerde yemek yemeden çıkmazdı en basit örneği olarak. Şimdi çok fazla dolmuyor. Yerel yönetimler turizm girişimciliğinin gelişmesi kapsamında destek olmuyor. Eğitim olarak turizm için bilgilendirme yapmışlardı ama uzun süre oldu."

K13:"Başta Akçakoca'nın tanıtılması gerekli. Festivaller ve etkinliklerle tanıtılmalı. Bunu yerel yönetimlerin yapması lazım. Amasra veya Safranbolu kadar tanınmalıyız. Bir tek Emitt Fuarına giderek olacak bir iş olduğunu düşünmüyorum. Tanınırsak turizm girişimciliğinin artacağını düşünüyorum. Akçakoca halkının bunu hak etmediğini, yatırım yapanlara ve işletme sahiplerine yazık olduğunu düşünüyorum. Yerel yönetimler bize destek veya eğitim sağlamıyor ama diğer işletmeler için bilemiyorum."

\subsection{Turizm Alanında Yapılan Girişimlerin Bölgeyi Ziyaret Eden Turistler Üzerinde Nasıl Bir Etki Oluşturduğu Düşüncesine İlişkin Bulgular}

Yapılan girişimlerin bölgeyi ziyaret eden turistlerde oluşturduğu etkinin ne yönlü olduğuna yönelik kod ve temalar Tablo 17'de sunulmuştur.

Tablo 17: Turizm Alanında Yapılan Girişimlerin Turistlerde Oluşturduğu Etki

\begin{tabular}{|c|c|c|}
\hline Tema & Kod ve Kategoriler & Katılımcılar \\
\hline \multirow{2}{*}{$\begin{array}{l}\text { Turizm alanında } \\
\text { yapılan } \\
\text { girişimlerin etkisi }\end{array}$} & Olumlu etki & $\begin{array}{l}\mathrm{K} 1, \mathrm{~K} 2, \mathrm{~K} 4, \mathrm{~K} 5, \mathrm{~K} 6, \mathrm{~K} 8, \mathrm{~K} 9, \mathrm{~K} 10, \mathrm{~K} 13, \mathrm{~K} 14, \mathrm{~K} 15, \mathrm{~K} 16, \\
\mathrm{~K} 17, \mathrm{~K} 18\end{array}$ \\
\hline & $\begin{array}{l}\text { Bir etki oluşturmadığı } \\
\begin{array}{l}\text { Akçakoca'daki sorunlardan } \\
\text { kaynaklı }\end{array}\end{array}$ & $\mathrm{K} 3, \mathrm{~K} 7, \mathrm{~K} 11,12$ \\
\hline
\end{tabular}

Turizm alanında yapılan girişimlerin bölgeyi ziyaret eden turistler üzerinde oluşturduğu etkiye yönelik iki katılımcının görüşü şu şekildedir:

K11:“Girişimler güzel ama Akçakoca'dan kaynaklı olarak etkisi olduğunu düşünmüyorum. Doğal güzellikleri kullanılamıyor ve taştan bir memlekete dönüşme yoluna gidiyor diye düşünüyorum."

K14:"Yani böyle girişimlerin olması güzel bir şey diye düşünüyorum. Farklı tarzda işletmelerin olması farklı insanlar demek. Herkese hitap edebilecek farklı tarzda girişimler yapılmalı çünkü olumlu yönde etkiliyor."

K18:"Olumlu etki oluşturduğunu düşünüyorum fakat reklam yeterince fazla yapılmalı. Daha önce ATV haberde İstanbul'da yaşayanlar için uzak değil diye bir program koydular. Burası aslında tavsiye edilmiş oluyor. Gelecek turist görüyor etkileniyor ve geliyor. Videodaki dalga kırandan gelip işletmeyi buluyor. Yani tanıtım olduğunda kimsenin bir şüphesi olmadan geliyor buraya. Fakat aktiviteyi arttıracak daha çok girişim yapılması gerektiğini düşünüyorum. Bunlar arttığında turistlerde daha çok olumlu etki bırakılabilir." 
5.12. Katılımcılara Göre Girişimcilikte Bulunmalarının Bölgedeki Kültürel ve Sosyal Aktivite İmkânlarını Nasıl Etkilediğine İlişkin Bulgular

Araştırmaya dâhil olan katılımcıların girişimcilikte bulunmalarının bölgedeki kültürel ve sosyal aktivite imkânlarını nasıl etkilediğine ve bu aktiviteleri arttırıp arttırmadıklarına yönelik kod ve temalar Tablo 18'de sunulmuştur.

Tablo 18: Katılımcıların Girişimcilikte Bulunmalarının Bölgedeki Kültürel ve Sosyal Aktivite İmkânlarına Etkisi

\begin{tabular}{l|l}
\hline Tema & Kod ve Kategoriler \\
\hline $\begin{array}{l}\text { Bölgedeki kültürel ve sosyal aktivite Olumlu etki } \\
\text { imkânlarına etkisi }\end{array}$ & Tüm katılımcılar \\
\hline $\begin{array}{l}\text { Kültürel ve sosyal aktiviteleri arttırıp Arttırdığı } \\
\text { arttırmadığı }\end{array}$ & Tüm katılımcılar \\
\hline
\end{tabular}

Girişimcilikte bulunmalarının bölgedeki kültürel ve sosyal aktivite imkânlarına etkisine yönelik bazı katılımcıların ifadeleri şu şekildedir:

K1:"Turizm girişimciliğinde bulunmamın bu bölgedeki aktivitelere etki ettiğini düşünüyorum. Ormanın yakında olma, balık tutma, ata binme, doğa gezileri, yayla gezileri vb. gibi birçok kırsal turizm aktivitelerini gerçekleştirmiş oluyorum. Benim gibi girişimcilerin olması diğer kişiler için cesaret oluşturuyor."

K2:"Turizm girişimciliğinde bulunmamın bu bölgedeki aktivitelere etki ettiğini düşünüyorum. İşletmemin tarihi yapılarıyla öne çıkan bir yerde bulunması ve buranın da aslında eskiden kalma bir yapı olması sebebiyle Akçakoca'da aktiviteleri arttırdığını düşünüyorum."

K3:"Turizm girişimciliğinde bulunmamın bu bölgedeki aktivitelere etki ettiğini düşünüyorum. Ata binme, kayık turları, mini survivor vs. gibi birçok aktivite seçenekleri kattığımı düşünüyorum. Fakat bizim önümüzün açıldığı takdirde kültürel ve sosyal aktivitelerin daha da artacağını düşünüyorum."

\subsection{Katılımcıları Akçakoca'nın Altyapı ve Üstyapı İmkânlarının Nasıl Etkilediğine İlişkin Bulgular}

Akçakoca'nın altyapı ve üstyapı imkânlarından nasıl etkilendiğine yönelik kod ve temalar Tablo 19'da sunulmuştur.

Tablo 19: Akçakoca'nın Altyapı ve Üstyapı İmkânlarının Etkisi

\begin{tabular}{|c|c|c|}
\hline Tema & Kod ve Kategoriler & Katılımcılar \\
\hline \multirow{5}{*}{$\begin{array}{l}\text { Akçakoca'nın } \\
\text { altyapı ve } \\
\text { üstyapı ı } \\
\text { imkânlarının } \\
\text { etkisi }\end{array}$} & Sorun olduğu düşüncesi & $\begin{array}{l}\mathrm{K} 3, \mathrm{~K} 4, \mathrm{~K} 5, \mathrm{~K} 7, \mathrm{~K} 10, \mathrm{~K} 11, \mathrm{~K} 12, \mathrm{~K} 15, \mathrm{~K} 16, \mathrm{~K} \\
17, \mathrm{~K} 18\end{array}$ \\
\hline & Olumsuz etkilendiği & $\begin{array}{l}\mathrm{K} 4, \mathrm{~K} 5, \mathrm{~K} 7, \mathrm{~K} 10, \mathrm{~K} 11, \mathrm{~K} 12, \mathrm{~K} 15, \mathrm{~K} 16, \mathrm{~K} 17, \\
\mathrm{~K} 18\end{array}$ \\
\hline & Olumsuz etkilenmediği & K3 \\
\hline & $\begin{array}{l}\text { Sorun olmadığı düşüncesi } \\
\text { Olumsuz etkilenmediği }\end{array}$ & $\mathrm{K} 8, \mathrm{~K} 13, \mathrm{~K} 14$ \\
\hline & $\begin{array}{l}\text { Önceden sorun olduğu düşüncesi } \\
\text { Artık olumsuz etkilenmediği }\end{array}$ & $\mathrm{K} 1, \mathrm{~K} 2, \mathrm{~K} 6, \mathrm{~K} 9$ \\
\hline
\end{tabular}


Akçakoca'nın altyapı ve üstyapı imkânlarından nasıl etkilendiğine yönelik bazı katılımcıların ifadeleri şu şekildedir:

K1: “Ulaşım ile ilgili sorunumuz var çünkü yıllardır bitmemişti. Yollar sebebiyle birçok misafir kaybı yaşamıştım. Dışarıdan gelen misafirler buranın yollarından korktuğu için girmek istemiyordu. Şuan yeni yeni yapılmaya başlandığından dolayı bundan sonra iyi etkiler diye düşünüyorum."

K5:"Eskiden musluktan su içilirken, şimdi içilmiyor. Kanalizasyon sistemlerinde bizim tesisimiz çok büyük bir yağmur yağdığında sular altında kalıyor. Ayrıca kalenin yolu çok iyi şekilde yapılmıyor ve kalenin uzun süredir çalışma halinde olması işletmemi çok etkiliyor. Belediyenin daha hassas olması gerektiğini düşünüyorum. Bu sebeple de olumsuz olarak etkiliyor."

K9:"Yollar sorunluydu onlarda düzeldi. Ben bir sorun yaşamıyorum ama başka yerlerde su kesintisi sebebiyle misafir kaybeden işletmeler olduğunu biliyorum."

\subsection{Akçakoca'da Turizm Girişimciliğinin Artmasını Tehdit Eden Unsurlara İlişkin Bulgular}

Akçakoca'da turizm girişimciliğinin artmasını tehdit eden unsurlar olup olmadığı ve var ise neler olduğuna yönelik kod ve temalar Tablo 20 'de sunulmuştur.

Tablo 20: Akçakoca'da Turizm Girişimciliğinin Artmasını Tehdit Eden Unsurlar

\begin{tabular}{|c|c|c|}
\hline Tema & Kod ve Kategoriler & Katılımcılar \\
\hline \multirow[t]{2}{*}{$\begin{array}{l}\text { Tehdit eden unsur } \\
\text { olup olmadığı }\end{array}$} & Tehdit unsuru olduğu düşüncesi & $\begin{array}{l}\mathrm{K} 1, \mathrm{~K} 3, \mathrm{~K} 5, \mathrm{~K} 6, \mathrm{~K} 7, \mathrm{~K} 8, \mathrm{~K} 9, \mathrm{~K} 10, \\
\mathrm{~K} 12, \mathrm{~K} 13, \mathrm{~K} 14, \mathrm{~K} 15, \mathrm{~K} 16, \mathrm{~K} 17\end{array}$ \\
\hline & Tehdit unsuru olmadığı düşüncesi & $\mathrm{K} 2, \mathrm{~K} 4, \mathrm{~K} 11, \mathrm{~K} 18$ \\
\hline \multirow{10}{*}{$\begin{array}{l}\text { Tehdit eden } \\
\text { unsurlar }\end{array}$} & $\begin{array}{l}\text { Yerel yönetim } \\
\text { Yerel yönetimin kendisi }\end{array}$ & $\mathrm{K} 3, \mathrm{~K} 7, \mathrm{~K} 15, \mathrm{~K} 16$ \\
\hline & Destek verilmemesi & $\mathrm{K} 5, \mathrm{~K} 6$ \\
\hline & Teşviklerin turizme verilmemesi & K7 \\
\hline & $\begin{array}{l}\text { Bürokrasideki engeller ve gerçekten teşvik almak isteyen } \\
\text { kişilerin projelerinin kurumlar tarafından mantıksız } \\
\text { görülmesi }\end{array}$ & K8 \\
\hline & $\begin{array}{l}\text { Tanıtım } \\
\text { Festivaller, etkinlikler ve reklam çalışmalarının yetersiz } \\
\text { olmasından dolayı misafirin azalması ve böylece } \\
\text { girişimcilerin cesaret edememesi }\end{array}$ & $\mathrm{K} 9, \mathrm{~K} 12, \mathrm{~K} 13$ \\
\hline & $\begin{array}{l}\text { İşletme sahipleri } \\
\text { Bilinçsiz işletme sahiplerinin misafir ile olan tavır ve } \\
\text { diyaloguna bağlı olarak misafirin azalması ve böylece } \\
\text { girişimcilerin cesaret edememesi }\end{array}$ & $\mathrm{K} 1, \mathrm{~K} 10, \mathrm{~K} 14$ \\
\hline & $\begin{array}{l}\text { Fiyatlama } \\
\text { Fiyatların yüksek olması ve fiyatlama konusunda hassas } \\
\text { olunmadığından dolayı misafir sayısının azalması ve } \\
\text { böylece girişimcilerin cesaret edememesi }\end{array}$ & $\mathrm{K} 5, \mathrm{~K} 17$ \\
\hline & $\begin{array}{l}\text { Turistik unsurlar } \\
\text { Turistik unsurlara önem verilmemesi }\end{array}$ & $\mathrm{K} 14$ \\
\hline & $\begin{array}{l}\text { Halk } \\
\text { Akçakoca halkının gelişime açık olmaması }\end{array}$ & $\mathrm{K} 13$ \\
\hline & $\begin{array}{l}\text { Hava şartları } \\
\text { Hava şartlarının diğer bölgelerle olan rekabeti düşürdüğü } \\
\text { bunun da turizmi sadece hafta sonuna yoğunlaştırmasına } \\
\text { sebep olduğu }\end{array}$ & K5 \\
\hline
\end{tabular}


Akçakoca'da turizm girişimciliğinin artmasını tehdit eden unsurlara yönelik bazı katıımcıların görüşleri şu şekildedir:

K3: "Yerel yönetimin kendisi olduğunu düşünüyorum. Turizmin gelişememesinde en büyük etkenler onlar olduğu için turizm girişimciliğinin artmasını tehdit den unsurun da onlar olduğunu düşünüyorum. Daha öncesinde insanlarımız en büyük etkendi ama şimdi Akçakoca insanı bunları aştı. Turizmin ne demek olduğunu ve nasıl gelir elde edeceğini öğrendi. Fakat bu sefer idare kaybetti."

K9: "Akçakoca'da festivallerin yapılmaması gibi ya da reklam çalışmaları gibi şeylerin yeterli olmamasından dolayı misafirin az gelmesinin tehdit unsuru olduğunu düşünüyorum. Bunun sonucu olarak da turizm girişimcileri işletme kurmaya cesaret edemiyorlar."

K14: "Buradaki işletme sahiplerinin tavrı ve turistik unsurlarımıza önem verilmemesi olduğunu düşünüyorum. Böyle olunca gelen misafir sayısının azalmasına bağlı olarak girişimcilerin cesaretlenememesi bence tehdit eden bir unsurdur."

K16: "Buradaki yerel yönetimlerin ve siyasetin turizm girişimciliğinin artmasını tehdit eden bir unsur olduğunu düşünüyorum."

\subsection{Akçakoca'da Turistik Unsurların Yeterince Değerlendirilip Değerlendirilemediğine İlişkin Bulgular}

Akçakoca'da turistik unsurların yeterince değerlendirilip değerlendirilemediği ve bunun etkisinin ne açıdan olduğuna yönelik kod ve temalar Tablo 21 'de sunulmuştur.

\section{Tablo 21: Turistik Unsurların Değerlendirilip Değerlendirilemediği ve Turizm Girişimcilerine Etkisi}

\begin{tabular}{cl|l}
\hline Tema & Kod ve Kategoriler & $\mathrm{Katılımcılar}$ \\
\hline \multirow{2}{*}{$\begin{array}{c}\text { Turistik unsurların } \\
\text { değerlendirilip } \\
\text { değerlendirilemediği }\end{array}$} & Değerlendirilemediği & $\mathrm{K} 1, \mathrm{~K} 2, \mathrm{~K} 3, \mathrm{~K} 4, \mathrm{~K} 5, \mathrm{~K} 6, \mathrm{~K} 7, \mathrm{~K} 8, \mathrm{~K} 11, \mathrm{~K} 1$ \\
\cline { 2 - 3 } & & $3, \mathrm{~K} 14, \mathrm{~K} 15, \mathrm{~K} 16, \mathrm{~K} 1, \mathrm{~K} 18$ \\
\cline { 2 - 3 } & Önceden değerlendirilemediği & $\mathrm{K} 10, \mathrm{~K} 12$ \\
\cline { 2 - 3 } & Değerlendirildiği & $\mathrm{K} 9$ \\
\cline { 2 - 3 } $\begin{array}{c}\text { Yeni yeni değerlendirilmeye } \\
\text { başlandığı }\end{array}$ & $\mathrm{K} 10, \mathrm{~K} 12$ \\
\hline \begin{tabular}{c} 
Turistik unsurların yeterince $\begin{array}{c}\text { değerlendirilip } \\
\text { değerlendirilemediğinin ne } \\
\text { açıdan etkilediği }\end{array}$ \\
\cline { 2 - 3 }
\end{tabular} & Olumsuz açıdan & $\mathrm{K} 1, \mathrm{~K} 2, \mathrm{~K} 3, \mathrm{~K} 4, \mathrm{~K} 5, \mathrm{~K} 6, \mathrm{~K} 7, \mathrm{~K} 8, \mathrm{~K} 11, \mathrm{~K} 1$ \\
\cline { 2 - 3 } & & $3, \mathrm{~K} 14, \mathrm{~K} 15, \mathrm{~K} 16, \mathrm{~K} 1, \mathrm{~K} 18$ \\
\hline
\end{tabular}

Akçakoca'da turistik unsurların yeterince değerlendirilip değerlendirilemediğine yönelik bazı katııımıı görüşleri şu şekildedir:

K3: "Akçakoca'da turistik unsurların değerlendirilemediğini ve önem verilmediğini düşünüyorum. Hepsi çok güzel değerlerimiz fakat ya yollarında sıkıntılar var ya da bakımları yok. Bana katkısı olumsuz oluyor. Şelale yoluna giderken görülebilecek ve şelaleden dönüşte uğranacak bir tesisim var fakat oraya giden sayısı az olduğunda bana katkısı az oluyor." 
K6:"Akçakoca'da turistik unsurların değerlendirilemediğini düşünüyorum. Yollarında sıkıntılar var, bakımları yetersiz ya da ulaşım sağlanmıyor. Örneğin, yağmur yağdığında çamurlu görüyor geri dönüyor ya da bebek arabalarını yürütemediği için gidemiyor. Bunlarda hem benim işletmemi hem de başka işletmeleri olumsuz etkiliyor."

K9:"Akçakoca'da turistik unsurların değerlendirildiğini düşünüyorum. Mesela belediyemiz Fakılı Mağarası'nı eskisinden daha tertipli hale getirdi. Yani oraya gelen misafirler oradan bana geliyor. Bu açıdan bakıldığında olumlu etkileniyorum."

K13:"Akçakoca'da turistik unsurların değerlendirilemediğini düşünüyorum. Ceneviz Kalesi uzun süredir restorasyon yapılacağı için kapalı halde. Gelen misafir kaleyi sorduğunda restorasyon halinde yerine kapalı denildiğinde bakmadan gidiyor gelen kişi. Bir daha da gelmiyorlar Akçakoca'ya. Bu sebeple hem değerlendiremiyoruz hem de turizmle ilgili eğitimimiz yok. Sonuç olarak olumsuz olarak etkileniyoruz."

\section{Tartışma ve Sonuç}

Bu araştırmada girişimcilik olgusu; turizm girişimciliği ve bölgesel kalkınma bağlamında incelenmiştir. Bu amaçla turizm girişimcileriyle görüşmeler yapılarak veriler elde edilmiştir. Veriler temalar altında çeşitli kategori ve kodlar haline getirilmiş ve bulgular sistemli bir şekilde ortaya koyulmuştur.

Elde edilen bulgulara göre, Akçakoca ilçesinde kadın turizm girişimcilerin ve genç yaşlarda girişimde bulunan kişi sayısının az olduğu ortaya çıkarılmıştır. Bu araştırmadaki turizm girişimcilerinin istihdam ettikleri kişi sayısı sezonlara göre farklılık göstermektedir. Bu da turizm girişimcileri için önemli bir sorun olan turizmin belli bir sezonda yoğunlaştığını göstermektedir. Turizm girişimcilerinin işletme faaliyet alanları, literatürde tanımlanan turizm girişimcilerinin işletme faaliyet alanlarıyla ve işletmeleriyle benzerlik gösterdiği sonucuna ulaşıımıştır. Katıımcıları turizm girişimciliğine yönelten nedenlerde Akçakoca'da olmayan bir şeyin yapılması sebebiyle girişimcilikte bulunan katılımcılar, Koh ve Hatten (2002)'e göre yenilikçi turizm girişimcisi olarak anılmaktadır. Ayrıca bireyler turizm piyasasının ihtiyaçlarına ilişkin yenilikçi yanıtlar aracılığıyla ekonomik yapıya yenilikler yapmaktadır (Nikolovski, 2017). Akçakoca'da turizm girişimcilerinin olmayan bir şeyi yapmaya yönelmesinin nedeni buna dayandırılabilir. Aydemir vd. (2011)'e göre, bu sebepler altında turizm girişimciliğine yönelen bireyler bölge ve yerel ekonomiyi canlandırarak, yeni iş imkânları getirmenin yanında gelir artışına katkıda bulunmaktadır. Bu sebeple de bölgelerin kalkınmasında önemli rol oynamaktadırlar. Ayrıca Balıkesir il merkezinde yapmış oldukları çalışmada turizm sektörüne yapılan yatırımların bölge kalkınmasına olumlu yönde etki ettiğine ulaşıımıştır. Turizm girişimcilerinin çoğunluğu 35 yaş ve üzerinde olup büyük bir kısmı da erkektir. Bu yönleriyle bu çalışmadaki bulgularla benzerlik göstermektedir.

Turizm girişimcilerinin çoğunluğunun işletme kurarken örnek aldığı bir işletme olmuştur. Turizm girişimcilerinin kurduğu işletmeler girişimci düşüncelerin ortaya çıkarılması ve anlaşılması bakımından önem arz etmektedir (Kale, 2016). İşletme yeri seçiminde öne çıkan faktör çoğunlukla kendine ait bulunan bir alanın olması iken hizmet seçiminde öne çıkan faktörler ise çoğunlukla Akçakoca'da böyle bir tesisin eksikliği, Akçakoca'da olmayan bir şeyin yapılması isteği, bu işe yatkın olunması ve bu işi iyi yaptığına olan inancı olmuştur. Turizm girişimcilerinin işletmelerine gelen ziyaretçilerin çoğunluğu yerli ve bölge dışındandır. Bu bulgu farklı bölgelerdeki ziyaretçiler yoluyla, geldikleri bölgedeki gelirin Akçakoca ilçesine taşınması bakımından önemlidir. Tüm bunlara bağlı olarak oluşturulan işletmeler ile sunulan hizmetlere karşı talebin artışıyla işletme kurulmasına ve bulunulan bölgenin cazip hale getirilmesine 
katkı sağlayacaktır. Yeni turistik işletmelerin farklı bölgelerde ortaya çıkışıyla da o bölgeler canlandırma ve motivasyon etkisi görecektir. Ayrıca, bölge halkının alım gücünün artmasıyla, refaha ulaşmaları sağlanarak sosyal ve toplumsal etki sağlanmaktadır (Özkul, 2008). İşletmeler turizm hizmetlerinin ve turist memnuniyetinin oluşturulmasıyla, olumlu bir hedef imajı sağlayabilme açısından önem taşımaktadır (Hallak vd., 2015). Bu sebeple de turizm girişimcileri Akçakoca ilçesi için kritik öneme sahiptir.

Girişimcilerin işletmelerinde yerel hizmetlere yer vermesi ve bölge içinden intiyaçlarını karşılamasına yönelik bulgu bölgedeki gelirlerin korunarak bölgede tutulduğunu göstermektedir. İstihdam edilen kişilerin çoğunlukla bölge içinden olduğu bulgusuna göre de, bölgede istihdam yoluyla gelirlere katkıda bulunulmaktadır. Başka bir bulguya göre, mevsimsellik sorunu girişimcilerinin tümünü etkileyen bir konudur. Turizm girişimcileri mevsimsellik sorunundan diğer girişimcilere göre daha çok etkilenmektedir. Bu sebeple de mevsimsellik konusunun oluşturduğu etkinin daha titiz ve etkin bir şekilde ele alınarak, mevsimsellik özelliğini azaltmaya yönelik politika ve stratejilerin izlenmesinin önem arz ettiği sonucuna ulaşılmıştır. Girişimciler çoğunluk olarak işletmelerine yönelik tanıtım ve reklam yapmakta ve bunun da tekrar ziyaret etme oranına olumlu etki ettiğini düşünmektedirler. Tanıtım ve reklam aracılığıyla tanınan işletmelerle, ziyaretçiler için bölgenin cezp edilmesi sağlanacaktır. Bunun yanında da bölgenin vergi tabanındaki büyüme, kişisel gelirlerdeki artış ve kar oluşumuyla sağlanmış olacaktır. Ayrıca girişimciler çoğunluk olarak ziyaretçilerine yenilikçi fikirler kapsamında geliştirdiği ürün ya da hizmetler sunmaktadır. Turizm ve konaklama pazarında turizm girişimcilik süreçleri birçok yeni turizm ürününün ve yenilikçi uygulamaların üretilerek piyasaya sürülmesine yol açmaktadır (Pırnar, 2015). Bu bulguya göre, Akçakoca ilçesindeki turizm girişimcileri yenilikçi uygulamaların üretilmesinde ve piyasaya sürülmesinde önemli bir rol üstlenmektedir.

Turizm intiyaçlarında artan taleple başa çıkılması bakımından turizm ürün ve hizmetlerinin çeşitlendirilmesi gerekmektedir. $\mathrm{Bu}$ da turizm girişimcilerinin arttırılmasıyla bağlantılı bir konudur. Bunlara yönelik olarak Akçakoca'daki turizm girişimcilerinin arttırılmasına yönelik neler yapılabileceğine ilişkin yollar girişimciler yoluyla sonuca ulaşmıştır. Öztürk (2013)'ün yapmış olduğu çalışmada da Beypazarı ve Safranbolu'da turizm girişimciliğinin gelişmeye açık bir potansiyele sahip olduğu sonucuna ulaşılmıştır. Bunun da turizm girişimciliğindeki başarı faktörlerinin belirlenerek, politikalar geliştirilmesi ile gerçekleşeceği ifade edilmiştir. Bu çalışmada elde edilen başka önemli bir bulguya göre, turizm girişimciliğinin gelişmesi kapsamında çoğunluk olarak yerel yönetimlerin destek olmadığı ve yerel yönetimlerin bölgede girişimciliğin teşvik edilmesi için eğitim ya da destek sağlamadığı sonucuna ulaşıımıştır. Koh'a (1996) göre ekonomik ve sosyal refaha katkı sağlayan turistik işletmelerin doğuşunun arttırılmasında en pratik yol yerli turizm girişimcilerinin arzının arttırılmasıdır. Bunun için de turistik girişim oluşturma sürecinin belirlenerek, turizm girişimciliğinin teşvik edilmesi için uygun politikalar geliştirilmesi önemli bir konudur. Turizm arzının turizm girişimciliğiyle sağlanması sebebiyle girişimciler olmadan turistik ürün ve gelişme, tanıtım ve turizm talebi konularından bahsetmek zorlaşmaktadır (Tekin ve Kasalak, 2014). Tüm bunlar sonucunda turizm girişimciliğinin gelişiminin sağlanması açısından yerel yönetimlere büyük görevler düşmektedir. Şengül (2017)'ün yapmış olduğu çalışmada bölgesel turizmin gelişmesinde yerel halkın girişimcilik eğilimlerinin attırılabilmesinde farkındalık yaratabilecek eğitimlerin gerçekleştirilmesi gerektiği sonucuna ulaşılmıştır. Ortaya çıkarılan başka bir sonuç da girişimcilerin devlet teşvikleri sağlanarak harekete geçirilmesidir. Bu konu için yerel yöneticilerin sağlayacakları eğitim ve teşvikler bölgede yaşayan halkın turizmden kazanç elde edebilmesi bakımından rolü önem arz etmektedir (Şengül, 2017). Çamur ve Cihangir 
(2017)'in yapmış oldukları çalışmada ise, turizm endüstrisinin ve turizme dayalı yerel girişimlerin desteklenmesinde mevzuatın ve merkezi-yerel hükümetlerin programlarının önem arz eden rolünün olduğu belirlenmiştir.

Akçakoca'da turizm alanında yapılan girişimlerin bölgeye gelen ziyaretçiler üzerindeki etkisinin olumlu olması, ziyaretçilerin intiyaçlarının karşılanabildiğini ve böylece turizmin gelişmesine katkı sağladığını gösteren önemli bir bulgudur. Kültürel ve sosyal aktivite imkânlarına olumlu etki ve bu aktivitelerin arttırılması gelen ziyaretçilerin Akçakoca ilçesini iyi yönlü deneyimleyebileceğini ifade etmektedir. Bu da hem turizm girişimcileri için hem de Akçakoca ilçesi için önem arz eden bir bulgudur. Girişimciler Akçakoca'nın altyapı ve üstyapı imkânlarından olumsuz etkilenmektedir. Bölgenin altyapı ve üstyapı sorunlarının çözülmesi; bölge kalkınmasının sağlanmasında, girişimciliğe olan ilginin artmasında, girişimcilik faaliyetlerinin devamlılığında ve yeni yatırımların yapılmasında hayati bir konudur. Akçakoca'da turizm girişimciliğinin çoğalmasını tehdit eden çeşitli unsurlar bulunmaktadır. Başka bir bulguya göre, Akçakoca'nın turistik unsurları yeterince değerlendirememesinden dolayı girişimciler olumsuz açıdan etkilenmektedir. Saylan (2011)'ın Balıkesir iline yönelik yapmış olduğu çalışmada da ilin turizm potansiyeli bakımından yeterince değerlendirilemediği, yeteri kadar girişimciliğin olmadığı belirlenmiştir. Bu bağlamda da girişimcilik kültürünün ortaya çıkarılmasıyla turizm sektörüne gerçekleştirilecek girişimcilik faaliyetlerinin bu ilin gelişmesi açısından önemli olduğu sonucuna ulaşılmıştır. Tüm bunlara göre, bölgeye ait olan ve ulaşılabilen turistik unsurlara yeterli önemin verilmesinin, sahip olunan turistik potansiyelin kullanılmasının hem bölge kalkınması hem de girişimciler açısından çözümlenmesi beklenen elzem bir konu olduğu belirlenmiştir.

\section{7.Öneriler}

Yapılan değerlendirmelere bağlı olarak araştırmada ulaşılan sonuçlara ilişkin önerilerde bulunulmuştur.

Bu çalışmada değerlendirilen alanların dışındaki turizm girişimciliği, genel olarak turizm girişimciliği profili veya diğer sektördeki girişimciler ile farklılıkları içeren bir çalışma yapılabilir. Bölgedeki turizm girişimcilerinin toplum tarafından desteklenmesi bakımından halka turizmin faydaları ve turizm girişimciliği ile ilgili bilgi verilebilir. Halkın bilinçlendirilerek dikkatinin çekilmesi turizm girişimciliğinin artabilmesi açısından önem arz etmektedir. Bölgenin tanınmasında ve turizm talebinin arttırılmasında yöreselliğin ön planda tutulması hem turizm girişimcileri için hem de bölge kimliği açısından önemlidir. Bu sebeple bu konuda geri kalan turizm girişimcileri işletmelerinde yöresel ürünlere yer verebilir. Akçakoca'nın eksikliklerinin ve ziyaretçi beklentilerinin giderileceği yatırımlara ve turizm kapsamında yenilikçilik özelliği baskın olan girişimcilerin projelerine öncelik olarak destek verilebilir. Bölgede yaşayan genç kesimin önü açılmalı ve ayrıca kadın turizm girişimci sayısının arttırılması yönünde çalışmalar yapılabilir. Turizme alternatif kazandıracak alanların belirlenerek ve girişimcilerin bu alanlara teşvik edilmesi sağlanarak Akçakoca'daki aktivite sayısı arttırılabilir. Örneğin; kırsal alanlara turizm girişimcileri teşvik edilebilir. Çünkü Akçakoca'nın kırsal turizm faaliyetlerine uygun altyapı ve eğilimleri vardır. Akçakoca'nın turistik unsurları çevresine girişimciler yönlendirilerek yeni işletmeler kurmaları teşvik edilebilir. Turistik unsurların bakımları ve güzergâh yollarına gerekli önem verilmeli, eksikleri giderilmeli ve sürdürülebilirliği sağlanmalıdır. Bunların kullanılamaması girişimcileri önemli derecede etkilemektedir. Akçakoca'daki turizmin 12 aya yayılmasını sağlayabilmek adına farklı düşüncelere sahip olan girişimciler ortak bir proje çerçevesinde buluşturularak gerekli mercilere ulaştırılması sağlanabilir. 
Altyapı ve üstyapı konusunda gerekli düzenlemelerin yapılması önem arz eden bir konudur. Bu durum özellikle altyapı ve üstyapıdan olumsuz etkilenen işletmeler için önemli bir sorundur. Katılımcı görüşlerine göre gelen ziyaretçiler ile iletişim konusunda işletme sahiplerine ve diğer esnaflara uzun süreli mecburi eğitim verilebilir. Ayrıca fiyatlama konusundaki dengesizlik sorunu düzenlenmeli ve gelen ziyaretçilerin bu durumdan olumsuz etkilenmesinin önüne geçilmelidir. Turizm destinasyonlarının önündeki en büyük sorunlardan biri olan mevsimsellik sorununun aşılması bakımından politika ve stratejiler izlenmelidir. Turizm girişimcilerinin de belirttiği görüşler üzerine düşük sezonlu dönemlerde çeşitli festival ve etkinlikler düzenlenerek, bölgenin arz kaynaklarına uygun olarak alternatif turizm türleri veya turistik ürünler geliştirilerek turizm talebi canlı tutulabilir.

Turistik unsurlara belediye tarafından ulaşım sağlama konusunda çalışma yapılabilir. Ulaşımın eksikliği sebebiyle güzergâh yolunda kalan turizm girişimcilerinin işletmeleri turistik unsurlara yakınlığının katkısını görememektedir. Turizm girişimciliğinin gelişmesinde tehdit olarak görülen yerel yönetimlerin, turizm girişimcilerinin başarılı olabilmesi için destek vermesi gerekmektedir. Bürokrasideki engeller ve turizm girişimciliğini kısıtlayacak engeller ortadan kaldırılmalıdır. Turizm girişimcilerinin daha geniş alanlara yayılabilmesi adına, kendi tanıtımlarını yapabilecekleri bir platform hazırlanabilir. Ayrıca Akçakoca'nın tanıtımı yapılırken her bölge tanıtıma eklenebilir, tanıtımayan bölgelerde bulunan turizm girişimcilerinin olumsuz etkilenmesi sonlandırılabilir.

\section{Kaynakça}

Ateljevic ve Li L. (2009), Tourism and Entrepreneurship (Editör: Jovo Ateljevic ve Stephen J. Page). Tourism Entrepreneurship-Concepts and Issues, ss.1032,UK: Elsevier.

Aydemir, B., Saylan, U. ve Özdemir, M. İ. (2011), Turizm Girişimciliği ve Bölgesel Kalkınma: Balıkesir Örneği. 1.Uluslararası Bölgesel Kalkınma Konferansı. 22-23 Eylül. Malatya: Fırat Kalkınma Ajansı, ss.551-559.

Bagherifard, M. S., Jalali, M., Jalali, F., Khalili, P. ve Sharifi, S. (2013),'Tourism Entrepreneurship Challenges and Opportunities in Mazandaran' Journal of Basic and Applied Scientific Research, 3(4), ss.842-846.

Ball, S. (2005),'The Importance of Entrepreneurship to Hospitality'Leisure, Sport and Tourism. Hospitality, Leisure, Sport and Tourism Network, 1 (1), ss.1-14.

Coşkun, R., Altunışık, R., Bayraktaroğlu, S. ve Yıldırım, E. (2015). Sosyal Bilimlerde Araştırma Yöntemleri (8. Baskı). Sakarya: Sakarya Kitabevi.

Çamur, C. K. ve Cihangir, E. (2017),'Turizm-Temelli Girişimciliğin Gelişiminde Yerel ve Mekânsal Dinamiklerin Göreme(Nevşehir-Kapadokya) Örneğinde Analizi' Yüzüncü Yıl Üniversitesi Sosyal Bilimler Enstitüsü Dergisi, 1 (Özel Sayı-3), ss.112.

Çeken, H. (2008),'Turizmin Bölgesel Kalkınmaya Etkisi Üzerine Teorik Bir İnceleme' Afyon Kocatepe Üniversitesi Iktisadi ve İdari Bilimler Fakültesi Dergisi, 10 (2), ss.293-306.

Dağlı, Z. (2018). 'Sürdürülebilir Turizmin Gelişimine Yönelik Yerel Halkın Tutumlarını Incelemeye İlişkin Bir Araştırma: Akçakoca Destinasyonu' Seyahat ve Otel İşletmeciliği Dergisi, 15 (3), ss.603-619.

Deale, C. C. (2016). 'Entrepreneurship Education in Hospitality and Tourism: İnsights from Entrepreneurs' Journal of Teaching Travel \& Tourism, 16 (1), ss.1-20.

Halis, M. ve Ulama, Ş. (2015),'Temel İşletmecilik ve Turizm Kavramları' (Editör: Burhanettin Zengin ve Şehnaz Demirkol). Turizm Işletmeleri, ss.19-50, İstanbul: Değişim Yayınları. 
Hallak, R., Assaker, G. ve Lee, C. (2015),'Tourism Entrepreneurship Performance: The Effects of Place Identity, Self-Efficacy, and Gender'Journal of Travel Research, 54 (1), ss.36-51.

Hollick, M. ve Braun, P. (2005), Lifestyle Entepreneurship: The Unusual Nature of the Tourism Entrepreneur Proceedings of the Second Annual AGSE International Entrepreneurship Research. Exchange. Swinburne Press, Melbourne, ss.1-17.

Kale, E. (2016),'Küçük Ölçekli Turizm Girişimciliğinin Özelliklerinin Belirlenmesi' Uluslararası Yönetim İktisat ve İşletme Dergisi, 12 (30), ss.159-173.

Kapu, H, Tutar, H, Özyakışır, D. (2012), Sivil Toplum, Girişimcilik ve Ekonomik Kalkınma, 1. Baskı, Ankara: Savaş Yayınevi.

Karataş, Z. (2017), 'Sosyal Bilim Araştırmalarında Paradigma Değişimi: Nitel Yaklaşımın Yükselişi' Türkiye Sosyal Hizmet Araştırmaları Dergisi, 1(1), ss.6986.

Kasalak, M.A. (2014),'Bölgesel Kalkınma Açısından Sosyokültürel Yapının Girişimciliğe Etkisi' SDÜ Fen Edebiyat Fakültesi Sosyal Bilimler Dergisi, 2014 (31), ss.249266.

Koh, Y. K. (1996),'The Tourism Entrepreneural Process: A Conceptualization and Implications for Research and Development'The Tourist Review, 51 (4), ss.2441.

Koh, Y. K. ve Hatten, S. T. (2002), 'The Tourism Entrepreneur' International Journal of Hospitality \& Tourism Administration, 3 (1), ss.21-48.

Kozak, N, Kozak, A. M. ve Kozak, M. (2015), Genel Turizm, Yenilenmiş 18.Baskı, Ankara: Detay Yayıncılık.

Lerner, M. ve Haber, S. (2001),'Performance Factors of Small Tourism Ventures: Ther Interface of Tourism, Entrepreneurship and The Environment' Journal of Business Venturing, 16 (1), ss.77-100.

Lordkipanidze, M., Brezet, H. ve Backman, M. (2005),'The Entrepreneurship Factor in Sustainable Tourism Development' Journal of Cleaner Production, 13 (8), ss.787-798.

Marangoz, M. (2017), Girişimcilik, Güncellenmiş 4. Baskı, İstanbul: Beta Yayıncılık.

Matsiliza, N.S. (2017), 'Seeking Strategies for Sustainability in Tourism Entrepreneurship in South Africa' African Journal of Hospitality, Tourism and Leisure, 6 (4), ss.1-10.

Mottiar, Z. (2015),'The Importence of Local Area as a Motivation for Cooperation Among Rural Tourism Entrepreneurs'Tourism Planning \& Development, 3 (2), ss.1-16.

Nikolovski, B., Dimoska, T. Ve Tuntev, Z. (2017), Effects of Tourism Entrepreneurship on Regional Development. Proceedings First International Scientific Conference. Challenges of Tourism and Business Logistics in the 21st Century. October 2425 \& December 2017.Gevgelija-Shtip,ss.111-120.

Nongsiej, P. ve Shimray, R. S. (2017), The Role of Entepreneurship in Tourism Industry: An Overview. In the National Seminar on Entrepreneurial Opportines for Educated Youth in Global Business. 8th March 2017. Pondicherry University, Puducherry, ss.1-10.

OECD (2003),Entrepreneurship and Local Economic Development, Programme and Policy Recommendations, France: OECD.

Önce, G.A. , Marangoz M. ve Erboy, N.C. (2014), Ekonomik Büyüme ve Kalkınmada Girişimciliğin Rolü ve Önemi. International Conference On Eurasıan Economies. 1-3 Temmuz 2014. Macedonia: Beykent University: ss.862-872.

Özkul, G. ve Dulupçu, M. A. (2007),'Kişisel Gelişsimin Girişimci Tipleri Üzerine Etkisi: Antalya-Isparta IIllerinde Bir İnceleme' ÇOMÜ Girişimcilik ve Kalkınma Dergisi, 2 (2), ss.67-92. 
Özkul, G. (2008), Girişimcilik Teorileri ve Girişimci Tipleri: Antalya-Burdur-Isparta İllerinde (İbbs Düzey 2 TR61 Bölgesinde) İmalat Sanayi Kobi'lerindeki Girişimciler Üzerine Bir İnceleme, Yüksek Lisans Tezi, Süleyman Demirel Üniversitesi, Sosyal Bilimler Enstitüsü, Isparta.

Öztürk, H. A. (2013),Turizmin Gelişiminin Girişimcilik Faktörleri Çerçevesinde Değerlendirilmesi: Beypazarı ve Safranbolu Üzerinde Karşılaştırılmalı Bir Çalışma, Yüksek Lisans Tezi, Gazi Üniversitesi, Fen Bilimleri Enstitüsü, Ankara.

Paksoy, Sadettin ve Aydoğdu, Mustafa H. (2010),'Bölgesel Kalkınmada Girişimciliğin Geliştirilmesi: Gap-Gidem Örnekleri' Girişimcilik ve Kalkınma Dergisi, 5 (1), ss.113-134.

Perktaş, E. (2014),'Bölgesel Kalkınma Özelinde Girişimciliği Ekonomik Kalkınma Sürecindeki Rolü' Akademik Sosyal Araştırmalar Dergisi, 2 (7), ss.472-486.

Pırnar, İ. (2015),'The Specific of Entrepreneurship Process in Tourism Industry'Selçuk Üniversitesi Sosyal Bilimler Enstitüsü Dergisi, (34), ss.75-86.

Russell, R. ve Faulkner, B. (2004),'Entrepreneurship, Chaos and The Tourism Area Lifecylce'Annal of Tourism Research, 31 (3), ss.556-579.

Rusu, S. , Csorba, L.M., Cureteanu R. , Isac, F. L. (2012),'Tourism Entrepreneurship and its Role in the Activity of SMEs in Romania' Journal of Economics and Business Research, 18 (2), ss.23-32.

Safian, S.A. (2012),'Social Entrepreneurship: Definition and Boundaries'Technology Innovation Management Review, February, ss.22-27.

Saylan, U. (2011), Girişimcilik Kültürü: Balıkesir'de Turizm Sektörüne Yönelik Bir Araştırma, Yüksek Lisans Tezi, Balıkesir Üniversitesi, Sosyal Bilimler Enstitüsü, Balıkesir.

Sheikh, R. M. (2015),Tourism Entrepreneurship Challenges and Possibilities in Small Tourism Businesses, Bachelor's Thesis, Centria University of Applied Sciences, Finlandiya.

Solvoll, S., Alsos, G. A. ve Bulanova, O. (2015),'Tourism Entrepreneurship-Review and Future Directions' Scandinavian Journal of Hospitality and Tourism, 15 (1), ss.120-137.

Stimson, J. R., Stough R. R. ve Roberts, H. B. (2006), Regional Economic Development: Analysis and Planning Strategy, Second Edition, Springer: Germany.

Şengül, S. (2017),'Yerel Girişimcilik ve Turizm İlişkisine Dair Çıkarımlar: Mudurnu Örneği' Yönetim ve Ekonomi Araştırmaları Dergisi, 15 (Ek Sayı 1), ss.126-142.

Tekin M. ve Kasalak, A. M. (2014),'Eko Turizm Girişimciliğinin Bölgesel Kalkınmadaki Rolü' Selçuk Üniversitesi Sosyal Bilimler Enstitüsü Dergisi, 32 (2014), ss. 129136.

Tokmak, C. ve İnce, C. (2014), Turizmde Çevreye Duyarlı Girişimcilik Yaklaşımı. VI. International Congress On Entrepreneurship. 24-26 Nisan. Kyrgyzstan/Bishkek: Atatürk Alatoo: ss.110-116.

Top, S.(2012), Girişimcilik Keşif Süreci, 2. Baskı, İstanbul: Beta Basım.

Yıldırım, A. ve Şimşek, H. (2005), Sosyal Bilimlerde Nitel Araştırma Yöntemleri (Güncelleştirilmiş Geliştirilmiş 5. Baskı), Ankara: Seçkin Yayıncılık.

Zurnacı, N. (2012), 'Kırsal Turizmde; Girişimcilik ve Örgütlenme' KMÜ Sosyal ve Ekonomik Araştırmalar Dergisi, 14 (23), 65-70. 
T.C.

DÜZCE ÜNIVERSITESI

BILIMSEL ARAŞTIRMA VE YAYIN ETIKK KURULU KARARLARI

TOPLANTI SAYISI

1
KARAR SAYISI

2020/2
KARAR TARIHİ

16/01/2020

\section{KARAR NO: 2020/2}

Düzce Üniversitesi Akçakoca Turizm İșletmeciliği ve Otelcilik Yüksekokulu öğrencisi Arzu Karagöz'ün Akçakoca'da kırsal turizm kapsamında değerlendirilebilecek alanlarında faaliyet gösteren 18 turizm girişimcisine yüz yüze görüşme yöntemi ile uygulamak istediği "Bölgesel Kalkınmada Turizm Girişimciliğinin Rolü: Akçakoca Örneği” başlıklı araştırmanın etik olarak uygun olduğuna,

Oy birliği ile karar verildi. 